
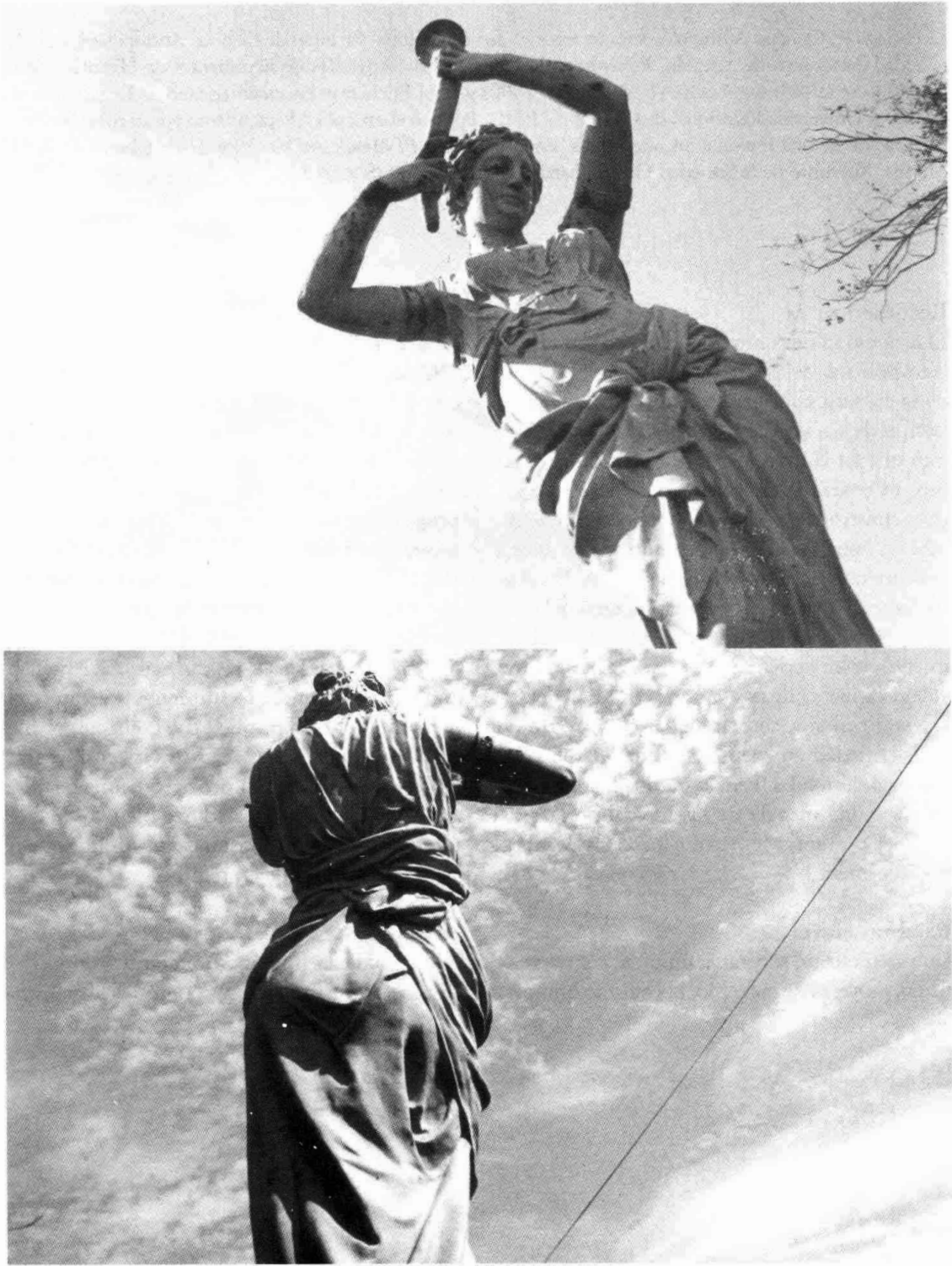


\section{Justo Miguel Flores Escalante}

Licenciado en Ciencias Antropológicas con especialidad en Historia, Facultad de Ciencias Antropológicas, Universidad Autónoma de Yucatán. Ponente en los Encuentros Nacionales de Estudiantes de Historia UNAM (1998), UAA (1999), UA-Camp. (1999), Udeg (2000) y en el Encuentro Latinoamericano de Estudiantes de Historia, Universidad Nacional de Colombia (2001). Publicó el artículo "¿Separatismo yucateco? o la difícil integración de una región a un nuevo país" en el periódico El Mundo al Día, 20 y 21 de febrero de 2001, Mérida. Miembro de la Sociedad Campechana de Historiadores (SOCAMHI).

\section{Resumen}

El artículo tiene como finalidad abordar el ámbito político de 1829-1831 desde el enfoque de la cultura política, haciendo hincapié en el campo de las ideas, en los discursos y debates más que en la práctica. En ese sentido abordamos el centralismo yucateco de 1829-1831, pues constituye un proyecto de gobierno sui generis en México ya que se adelanta varios años a la primera república central mexicana. En él se plantean la visión de soberanía unitaria del centralismo contra el contractualismo; el fortalecimiento de los poderes ejecutivo y judicial frente al legislativo; la disposición de crear una democracia dirigida y, con ello, de excluir al grueso de la sociedad en cuanto a la ciudadanía y los procesos electorales. Para lograr lo anterior, se recurría a una mezcla de las ideas liberales de Locke, Constant, Montesquieu con las del antiguo régimen.

\section{Palabras clave:}

Cultura política, soberanía unitaria, contractualismo, proyecto de gobierno, liberalismo burgués.

\section{Abstract}

The article examines the political sphere of 1829 to 1831 from the perspective of political culture, emphasizing the field of ideas in discourse and debate more than in practice. In this respect, it deals with Yucatecan centralism from 1829-1831, which constitutes a government project that was unique in Mexico, since it was several years ahead of the First Mexican Central Republic. It contained the vision of an unitary sovereignty of centralism as opposed to contractualism; the reinforcement of the executive and judicial branches vis-à-vis the legislative branch and the willingness to implement a directed democracy which implied the exclusion of the majority of society as regards citizenship and electoral processes. In order to achieve these aims, government resorted to a blend of liberal ideas from Locke, Constant and Montesquieu and those of the ancien regime.

Key words:

Political culture: unitary sovereignty; contractualism: government projects; bourgeois liberalism.

Fecha de recepción: diciembre de 2003

Fecha de aceptación: octubre de 2004 


\title{
El primer experimento centralista en Yucatán: el proyecto de gobierno de José Segundo Carvajal (1829-1831)
}

\author{
Justo Miguel Flores Escalante
}

$\mathrm{L}$ a llegada de los tiempos independientes para América también significó épocas de inestabilidad política. En la búsqueda de proyectos de gobierno que llenaran el vacío del poder colonial roto y que dirigieran el rumbo de los nacientes Estados, se abandonó en muchas ocasiones el campo de las ideas por el de las armas. Sin embargo, como ha señalado buena parte de los historiadores actuales, entre ellos Carmagnani, Annino y Vázquez, ${ }^{1}$ las variaciones de gobierno, más que anarquía, indicaron la búsqueda

${ }^{1}$ Josefina Vázquez, en sus múltiples trabajos escritos y coordinados, expone que la formación del Estado mexicano fue compleja por surgir de regiones muy distintas, lo cual también creó inestabilidad en el gobierno general, que experimentó formas de organización política para unificar y dirigir a un Estado tan disímil, pero siempre a través de proyectos de gobierno. Vázquez, "Difícil", 1994 y "México", 1995. Por otra parte, Carmagnani habla de la relación de la territorialidad, vecindad y ciudadanía de los pueblos y provincias dentro de la formación de la nación mexicana. Carmagnani, "Territorios", 1994.

Annino opina sobre los primeros años de vida independiente de México, "Una sociedad con fracciones políticas que luchaban entre sí en distintas formas, que buscaron constantemente solucionar el problema de la mejor forma de gobierno experimentando distintas hipótesis, federal, centralista, hasta censataria. Una época de gran fluidez e inestabilidad que sin embargo no puede ni debe ser considerada como un de un sistema gubernativo ideal. A pesar de que la primera mitad del siglo Xrx está marcada por efímeros regímenes, había la voluntad para gobernar, pues existieron proyectos de gobierno y de nación-Estado de los diferentes grupos de poder que pretendían dirigir el rumbo del país.

El mes de noviembre de 1829 marcó para Yucatán una nueva época en su vida. Atrás quedaban los días en donde los conflictos políticos terminaban dentro de este mismo ámbito. En esa fecha, el campo de los discursos y las elecciones fue abandonado para dar paso a los "golpes militares" y al camino de las armas. En Yucatán se empezarían a vivir los tiempos de guerra como acontecía en las demás naciones de Hispanoamérica, y con el gobierno general de México a partir de la independencia.

Desde entonces se inició un reacomodo político que tendía a la disolución de los parridos regionales de la Camarilla y la Liga [grupos políticos yucatecos herederos del sanjuanismo o liberalismo gaditano ${ }^{2}$ y riva-

periodo de 'anarquía' sino por lo que fue: unas décadas de experimentación dramática de soluciones a los problemas creados por la quiebra del orden imperial y monárquico". Annino, "Nuevas", 1995, p. 52.

${ }^{2}$ El movimiento liberal sanjuanista comenzó con las cátedras de Pablo Moreno en el Seminatio Tri- 
les entre sí]. En este proceso jugó un papel muy importante el golpe militar de $1829 .^{3}$

En este trabajo abordaremos el proyecto de gobierno ${ }^{4}$ creado a partir del golpe dado por los militares en noviembre de 1829, un movimiento sui generis pues instauró el centralismo en Yucatán años antes de la primera república centralista. Por tal motivo, este experimento de gobierno ofrece un importante campo de

dentino de Mérida. Entre sus alumnos se contaba a Andrés Quintana Roo, Lorenzo de Zavala, Manuel Jiménez Solís, Manuel García Sosa, Francisco Bates y José Mariano de Cicero, quienes se reunían en la sacristía de la iglesia de San Juan, en la capital yucateca, bajo la dirección del párroco José María Velázquez. Este grupo fue ferviente partidario del liberalismo gaditano, el cual adoptó. Si se quiere saber más sobre los sanjuanistas véase Lanz, Compendio, 1905, pp. 108109; Ancona, Historia, 1978, t. III, caps. II y III; Castillo y Domínguez, "Impacto", 1986; Campos, "Política", 1995. Por otra parte, la camarilla estaba integrada principalmente por Pedro Manuel Regil, Joaquín García Rejón, Lorenzo Peón y Pedro Almeida; su líder era Pedro José Guzmán. En contraparte, el grupo de la Liga estaba conformado por Eusebio Villamil, Cresencio José Pinelo, Ciprián Blanco y José Matias Quintana, su jefe era José Tiburcio López. Si el lector desea conocer más al respecto puede consultar Ancona, Historia, 1978, t. III, pp. 313-314; Lanz, Compendio, 1905, p. 170; Campos, "Autonomía", 1999 , caps. I y II; Zanolli, "Liberalismo", 1989, pp. 415-416.

${ }^{3}$ Campos, "Política", 1995, p. 389.

${ }^{4}$ Se entiende por proyecto de gobierno, la estructura político-administrativa que se pretende establecer o implantar para dirigir y organizar la vida pública de Yucatán, es decir, cómo se arman los poderes de la entidad y qué relaciones guardan entre sí, principalmente el ejecutivo y el legislativo, el papel que desempeñan el habitante-ciudadano, los cabildos y los procesos electorales. El analizar el concepto de soberanía con respecto a estas instituciones me permitirá identificar sus bases ideológicas. estudio acerca de las ideas de los políticos yucatecos que, desde la península, plantearon una opción de gobierno con miras a ocasionar la caída del sistema federal y muestra el ritmo político discordante de Yucatán en ciertos momentos coyunturales de la historia mexicana.

Antes de entrar en materia haré una breve semblanza de la situación política peninsular en 1829. Posteriormente discutiré la formación y consolidación del proyecto centralista en 1830 en los siguientes planos: la sustitución de autoridades iniciada por José Segundo Carvajal; la convocatoria a elecciones para la Junta de Bécal; los postulados de ésta y el proceso electoral para la Junta de Calkiní. De estos apartados se desprenderá el análisis de la división de poderes, el concepto de ciudadanía y soberanía que plantearon los centralistas y que conformaron su proyecto. El estudio mostrará algunos aspectos de la cultura política ${ }^{5}$ de los actores políticos, en particular las bases ideológicas que dieron sustento a su proyecto de gobierno.

${ }^{5}$ Cultura política es un concepto utilizado "para designar el conjunto de acritudes, normas y creencias, compartidas más o menos ampliamente por los miembros de una determinada unidad social y que tienen como objeto los fenómenos políticos. Forman parte de la cultura política de una sociedad, los conocimientos, o mejor dicho su distribución entre los individuos que la componen, relativos a las instituciones, a la práctica política, a las fuerzas políticas que operan en un determinado contexto; las orientaciones más o menos difundidas, por ejemplo, la indiferencia, el cinismo, la rigidez, el dogmatismo o, por el contrario, el sentido de confianza, la adhesión, la tolerancia hacia las fuerzas políticas distintas de la propia, etc., y, finalmente, las normas, como por ejemplo, el derecho y el deber de los ciudadanos de participar en la vida política, la obligación de aceptar las decisio- 


\section{EL ESCENARIO POLÍTICO EN TIEMPOS \\ DE LóPEZ CONSTANTE, 1825-1829}

El caso de Yucatán resalta entre las regiones de América porque vivió el cambio hacia la vida independiente de manera pacífica y por lo tanto no tuvo desgarramientos internos. Los primeros años de la vida independiente fueron relativamente tranquilos, lo que permitió al estado tener comicios electorales y no llegar a las armas para imponer gobernantes. En 1825 salieron vencedores José Tiburcio López Constante ${ }^{6}$ y su grupo la "Liga" por encima de Pedro Manuel Regil y sus partidarios de la "Camarilla", en lo que

nes de la mayoría, la exclusión o no del recurso a formas violentas de acción. No hay que olvidar, por último, el lenguaje y los símbolos, específicamente los políticos, como las banderas, las contraseñas de las diversas fuerzas políticas, las consignas, etc. Bobbio, Matteucci y Pasquino, Diccionario, 1997, t. If, p. 415.

${ }^{6}$ José Tiburcio López Constante fue uno de los políticos más destacados de la primera mitad del siglo xix en Yucatán, fue miembro de la Junta Provisional Gubernativa yucateca en 1823. Después del gobierno de Santa Anna en Yucatán (1824) y de la promulgación de la Constitución de 1825 yucateca, fue el primer gobernador electo, luego se reeligió y fue derrocado en 1829. Al caer el régimen de Carvajal ocupó brevemente la gubernatura en 1832 y siguió figurando en la vida política yucateca. En 1844, durante el periodo más álgido en las relaciones entre el gobierno general y Yucatán, por la separación e integración de la península (1840-1848), dicho personaje fue gobernador interino. López Constante, distinguido miembro del grupo de la "Liga", se convirtió en partidario del federalismo y fue aliado de otros destacados actores políticos yucatecos (del puerto de Campeche) como Santiago Méndez y Juan de Dios Cosgaya, ambos gobernadores de la península en diferentes periodos. Si el lector desea conocer más sobre el mencionado político yucateco puede consultar Lanz, Compendio, 1905. los autores decimonónicos yucatecos han denominado la elección más limpia de la primera mitad de los años independientes. ${ }^{7}$ Aún los procesos electorales no eran utilizados para "legalizar" a los gobiernos impuestos por las armas o "golpes de Estado". Sin embargo, durante el periodo gubernamental de López Constante, 1825-1829, se suscitaron conflictos con el gobierno general por el pago de alcabalas e impuestos sobre el comercio marítimo, el pago de la milicia y los gastos para enfrentar una posible invasión española en 1829.

La inestabilidad política nacional también repercutió en Yucatán. En 1828, Vicente Guerrero derrocó a Manuel Gómez Pedraza; Guerrero a su vez fue separado de la presidencia por el golpe militar dado por Anastasio Bustamante y Santa Anna en 1829 , año en que el insurgente fue asesinado, acontecimientos que provocaron el descontento entre la población y el mismo gobierno yucateco. El contexto era bastante delicado, tanto que el 21 de septiembre de 1829 el Congreso yucateco

${ }^{7}$ Ancona, Historia, 1978, t. III, pp. 307-317; Molina, Historia, 1921, t. I, p. 69. Autores de la historiografía yucateca han cuestionado los planteamientos de aurores decimonónicos sobre la estabilidad política de 1825-1829, afirmando que también fue una época intranquila y de constantes tensiones. Véase Campos, "Política", 1995, cap. IV.

${ }^{8}$ Bellingeri, "Voto", 1995, "Soberanía", 1995 y "Ambigüedades", 1995; Annino, Historia, 1995, son dos de los autores que más han trabajado sobre los procesos electorales en Iberoamérica durante las primeras décadas del siglo XIX. El primero se ha enfocado en Yucatán y resalta su excepción al no tener movimientos armados independentistas y mantener comicios electorales relativamente tranquilos en la primera década independiente. 
decretó "que no se anticipe cantidad alguna a las cajas de la federación sin previa calificación de urgencia y de su justa inversión, ni se haga pago alguno que no esté determinado precisamente por la ley". ?

Como señala Bellingeri, ${ }^{10}$ no existía una cultura política que permitiera la alternancia de los diferentes grupos de poder. Las elecciones de 1829 fueron manejadas de tal forma que el grupo contrario a la "Liga", la "Camarilla", quedó marginado de los escaños políticos. La coyuntura para el cambio se estaba dando. Se vislumbraba el arribo al poder por medio de las armas. Aunado a estos factores, estaba el descontento de propietarios y estratos del clero ante el sistema de gobierno que no protegía sus intereses.

El enfrentamiento con los jefes militares ocasionó un choque de poderes que finalmente hizo caer al gobierno de López Constante. El general Felipe Codallos, comandante general de la guarnición nacional en Yucatán, reclamaba del gobierno el sostenimiento de las tropas pero, ante la escasez del erario, José Tiburcio López Constante se lo negó. Codallos fue llamado a México y su sucesor, José Segundo Carvajal, ${ }^{11}$ continuó el conflicto

9 Archivo General del Estado de Yucatán (en adelante AGEY), fondo Congreso, ramo Decretos, 1829, vol. 7, exp. 1, f. 26.

${ }^{10}$ Bellingeri, "Voto", 1995, pp. 112-119.

11 José Segundo Carvajal, a pesar de su investidura militar, fue uno de los políticos más influyentes en Yucatán durante los primeros años de la independencia. En 1820 juró la Constitución gaditana y, siendo elector por Campeche, pidió que la ciudad tuviera una representación permanente en la Diputación Provincial yucateca. En 1823, año clave para la formación de la federación mexicana, Carvajal era go- que culminó con el pronunciamiento de la guarnición de Campeche con el apoyo de sus similares de Bacalar, Champotón, Sisal, Carmen y Mérida. ${ }^{12}$

El pronunciamiento militar tuvo éxito por el apoyo de los militares, los políticos de la camarilla, los que se perfilaban a favor del centralismo y los clérigos que estaban a favor de José María Guerra y de la caída de José María Meneses. Estas fuerzas actuaban en contra de un gobierno que se consideraba débil e incapaz de procurar la felicidad de los yucatecos.

bernador y capitán general de Yucatán hasta que fue reemplazado por la Junta Provisional Gubernativa. En 1824 dirigió el batallón llamado la "Columna", con el fin de someter al Ayuntamiento de Campeche que se oponía a los mandatos de las autoridades yucatecas, porque éstas no habían declarado la guerra a España. Su participación más importante fue de 1829 a 1832, cuando intentó establecer el centralismo en Yucatán. A partir del golpe dado en 1829, los militares yucatecos adquirieron gran importancia para inclinar la balanza a favor de los centralistas y federalistas regionales. Entre los militares más destacados y que en algún momento fueron aliados cle Carvajal encontramos a los campechanos Pedro Sainz de Bamnda, Sebastián López de Llergo, Pablo Lanz y Marentes, a quienes se les uniría el cuñado de Santa Anna, Francisco de Paula Toro. Después de 1832 la participación política de Carvajal se redujo drásticamente. Aunque nació en Mérida, buena parte de su vicla permaneció en Campeche, donde murió. Los acontecimientos políticos en los que participó Carvajal se pueden consultar en Lanz, Compendio, 1905; Ancona, Historia, 1978, t. III; y Molina, Historia, 1921, t. I.

${ }^{12}$ Estos acontecimientos se pueden consultar en los libros de historia de Yucatán escrita por autores decimonónicos. Por ejemplo, Ancona, Mistoria, 1.978, t. III, pp. 319-325; Lanz, Compendio, 1.905, pp. 73-78. 


\section{LA INSTAURACIÓN DEL CENTRALISMO YUCATECO: LA SUSTT'TUCIÓN DE AUTORIDADES}

Llegado el fin del conflicto entre los militares y el gobierno de López Constante, que culminó con el levantamiento promovido por la guarnición de Campeche y secundado por varias guarniciones de la península el 5 de noviembre de 1829, los seguidores de Carvajal proclamaron la instauración del centralismo. Dado el derrocamiento del gobierno de López, los diferentes sectores descontentos, como camarilleros, comerciantes y parte del clero, se sumaron a los pronunciados. ${ }^{13}$

Los partidarios del nuevo régimen se encargaron de sustituir a sus detractores $\mathrm{y}$ antiguas autoridades del gobierno anterior, por ejemplo, en Peto, capital del partido de Beneficios Altos, simpatizantes de Carvajal pidieron la destitución del coronel Antonio Gutiérrez del $8^{\circ}$ batallón de la localidad por negarse a abrazar el centralismo. Entre los solicitantes se encontraban figuras que desempeñaron un papel importante más adelante: Wenceslao Alpuche, Diego Crisanto Andrade,

${ }^{13}$ Melchor Campos, menciona la aspiración que tuvieron los comerciantes y camarilleros de impulsar el sector agroindustrial como se había hecho en la época de las reformas borbónicas, implementando el libre comercio, liberando de las cargas fiscales al sector mercantil y favoreciendo la introducción de granos a la península; la sola idea de estas reformas propició la coalición de las elites con los militares. Aunado a ello, los intereses regionalistas y separatistas de los camarilleros, para resaltar la excepción de Yucatán dentro de México, plantearon el sistema centralista para el estado y el país y, contradictoriamente, harían respetar las necesidades de la península frente al poder central del gobierno general. Campos, "Política", 1995, pp. 400-403, 430-431, 497, 571-574.
Vicente Antonio Yenro; los militares José Pinto, Ciprián Montalvo, José Antonio Montalvo, entre otros. ${ }^{14}$

También en Maní hubo denuncias contra los militares "tibios" del lugar, los oficiales Dionicio Pacheco, Gerónimo Ocampo y Francisco Becerra fueron acusados de no abrazar el centralismo. No obstante, se quedaron en sus puestos al manifestar su adhesión. ${ }^{15}$

Mientras tanto, José Segundo Carvajal se apresuraba a sustituir a las autoridades del régimen anterior, comenzando con las más inmediatas a los pueblos, los ayuntamientos. El control de los cabildos era crucial para el nuevo gobierno, porque eran los representantes más cercanos de la población y las figuras clave en el primer nivel de elección, las parroquias. Además, los ayuntamientos habían heredado de la época gaditana y de la independencia la soberanía de los pueblos frente a la soberanía estatal y nacional.

De ahí que Annino mencione que, en realidad, no eran los panfletos y proclamas militares los que sustentaban o legalizaban a los gobiernos golpistas o a los militares, sino los cabildos, instituciones depositarias de la voluntad de los pueblos, según la visión contractualista americana. ${ }^{16} \mathrm{Y}$ fue en el control de los pueblos

${ }^{14}$ También figuraron Felipe López, el subteniente Darío Arceo, Sebastián López, Sandino Escalante, el teniente Leonardo Arceo, el teniente Pablo José Arceo, el subteniente Andrés Vázquez, el subteniente Juan de la Rosa, Macedonio Dzul, José María Rivera, etc. Centro de Apoyo a la Investigación Histórica de Yucatán (en adelante CAIHY), manuscritos, documentos sueltos, c. XXXI-1826, doc. 017, 1829.

${ }^{15}$ AGEY, fondo Poder ejecutivo, ramo Gobernación, 1829 , vol. 4 , exp. 4, fs. $158 \mathrm{v}$ y 175 .

${ }^{16}$ Annino menciona que durante la crisis imperial se fueron formando tres especies de soberanías: 
donde primeramente se empezó a esbozar la visión unitaria de los centralistas, al menos en el interior de Yucatán, pues se trataba de concentrar el poder en las instancias estatales. ${ }^{17}$

Por esa razón había que congraciarse con los habitantes de los pueblos y mostrar los beneficios del nuevo régimen, liberándolos de las cargas que pagaban los ayuntamientos, como el caso de una representación hecha por los vecinos de Dzitbalché, partido de Hecelchakán, que

la de la nación, la de las provincias y las de los municipios, y que la primera república federal intentó institucionalizarlas a través del liberalismo constitucional. Recuerda además que cada carta constitucional venía precedida de un plan y de un levantamiento, lo que significaba que los cuerpos territoriales delegaban su representación en los caudillos. Esto no era necesariamence un fenómeno militarista, pues la legitimidad del levantamiento era dada por los documentos de adhesión de municipios y estados. "El levantamiento era, pues, un acto fuertemente institucionalizado por medio del cual unos cuerpos electivos rompían el pacto de subordinación al gobierno y apoyaban a otros cuerpos recuperando su soberanía. La dinámica de los levantamientos, desde su proclamación hasta las actas de adhesión, y al fin de la convocatoria de un Congreso Constituyente, muestran claramente que, fueran los gobiernos federales o centralistas, la lucha política se encauzaba en un patrón de luchas diferentes". Annino, "Nuevas", 1995, pp. 68-69.

${ }^{17}$ Desde la época gaditana se vislumbraron dos tipos de visiones de soberanía de la nación. Los españoles al estilo francés consideraron a la nación como una unidad abstracta en la que esencialmente residía la soberanía, mientras que los criollos americanos vieron a la nación como plural, es decir, compuesta por reinos, virreinos, territorios, provincias y cabildos, los cuales nunca delegaban totalmente la soberanía a las instituciones, pues sólo originariamente se depositaba en la nación. Consultar Annino, "Ciudadanía", 1999: p. 76; Guerra, "Soberano", 1999, pp. 36-39. pidieron la suspensión de los gravámenes de los arbitrios municipales, y que le resolvió a su favor. ${ }^{18}$

José Segundo Carvajal se apresuró a dominar los cabildos colocando a militares, como en el caso de Campeche, o bien, a civiles partidarios del centralismo, como sucedió en Mérida. Para tener un férreo control en la península, aparte de los ayuntamientos se nombró un jefe político subalterno, que generalmente era un oficial militar, con el fin de extender el poder del jefe político superior para regular y controlar las disposiciones de los cabildos, incluso el mismo jefe político superior intervino en las sesiones de los ayuntamientos. ${ }^{19}$ Es importante señalar esto, porque muestra la concentración del poder en el ejecutivo estatal, quien no debía intervenir en las sesiones del cabildo, como se había señalado en la época de la Constitución gaditana ${ }^{20} \mathrm{y}$, en cierta manera, se respetó con el gobierno federal de Yucatán, lo que significa que al régimen centralista le interesaba mantener bajo su rectoría la soberanía de los cuerpos municipales.

En la ciudad de Campeche varias personas fueron "electas" para el cabildo de

${ }^{18}$ AGEY, fondo Poder ejecutivo, ramo Gobernación, 1829, vol. 2, exp. 4, 168v.

${ }^{19}$ En las sesiones del Ayuntamiento de Mérida de 1830 y 1831 podemos notar lo mencionado, en especial los días primero de enero de 1830 y el 27 y 30 de junio de 1831. CAIHY, manuscritos, Acta de cabildo núm. 22, fs. 1-1v y 213v.-220v.

${ }^{20} \mathrm{La}$ Constitución gaditana no concedía voto a los jefes políticos en los acuerdos de los ayuntamientos. En tanto se recalca que aquél era propio de los síndicos y alcaldes. Esta circular fue emitida para todas las provincias de ultramar desde Cádiz, el 13 de julio de 1813. AGEY, fondo Colonial, ramo Reales cédulas, 1.813 , vol. 2, exp. 8 . 
1829-1830, entre las que destacaron militares retirados y partidarios del régimen centralista. Sin embargo, algunos de los nombrados presentaron su renuncia, por. ejemplo, el teniente retirado José Lavalle, nombrado alcalde segundo, y don Juan Estrada, regidor primero, a quienes se los eximió de su cargo. No así al síndico procurador segundo Pedro Méndez, y a los regidores Mauricio Molina y Benedicto Campos. ${ }^{21}$ El jefe político subalterno de Campeche electo para los años de 1830 y 1831 fue Francisco de Paula Toro, ${ }^{22}$ sin embargo, el alcalde primero, Joaquín Ruiz de León, ${ }^{23}$ conservó su investidura de máxima cabeza del cabildo campechano, pese a perder la jefatura política. Mientras tanto, el Ayuntamiento de la capital fue totalmente reemplazado.

Lo gravoso de las cargas fiscales sobre el comercio de Yucatán causó un profun-

${ }^{21}$ AGEY, fondo Poder ejecutivo, ramo Gobernación, 1829, vol. 2, exp. 4, fojas 164v, 172-172v, 174$174 \mathrm{v}$

${ }^{22}$ Alcocer, Historia, 1991, p. 69. Una figura clave de la caída de mandatarios en Yucatán fue Francisco de Paula Toro, quien derrocaba o apoyaba a las autoridades según las políticas que desde el centro del país llevaba a cabo su cuñado Santa Anna. En 1832, ante la desidia del grupo de Carvajal de favorecer a su hermano político para derrocar a Bustamante, Toro hizo alianzas con los partidarios de López y derrotó a aquéllos. Luego, sus aliados federalistas por similares motivos por los que cayeron los centralistas, se convirtieron en los enemigos del comandante y fueron removidos de nuevo en 1834, cuando Santa Anna se enfrentó a Valentín Gómez Farías, con lo que obtuvieron el poder una vez más los centralistas. De 1835 a 1837, Toro se impuso como gobernador de Yucatán rompiendo de esta manera con los militares locales, en 1837 salió de la península desprestigiado. Véase Ancona, Historia, 1978, t. III; Lanz, Compendio, 1905; Molina, Historia, 1921, t. I, pp. 124-125.

${ }^{23}$ Alcocer, Historia, 1991, pp. 67-69. do malestar entre los comerciantes del puerto de Campeche, razón por la cual participaron en el nuevo gobierno. En los años 1830 y 1831 diez de los 18 (incluido el secretario) miembros del cabildo campechano eran comerciantes. Algunos no habían participado en anteriores gobiernos y sus nombres sólo figuraron en los tiempos del régimen centralista. ${ }^{24}$

En Mérida, las nuevas autoridades del Ayuntamiento fueron: alcalde primero, Pedro Elizalde; alcalde segundo, Félix Antonio Fajardo, y alcalde tercero, José Cruz Villamil, entre otros capitulares que tuvieron un desempeño activo en el régimen. $\mathrm{El}$ jefe político subalterno designado fue el teniente coronel Juan Manuel Calderón. ${ }^{25}$

Sin embargo, para 1830 aún no se legalizaba del todo el régimen de Carvajal, la presión nacional que se ejercía sobre Yucatán y la oposición de los derrocados dejaba a su gobierno en una posición endeble, y sus opositores lo mostraban como usurpador e ilegal. Ante esta situación, el grupo de Carvajal tuvo que aparentar

${ }^{24}$ Se puede consultar la lista de comerciantes y empresarios que presenta Betty Zanolli y notar que buena parte de estas personas sólo participaron en cargos políticos bajo los regímenes centralistas, cuyo número era mayor que en los gobiernos federales. Como ya mencionamos, para los años de 1830 y 1831, diez de los 18 miembros del cabildo campechano eran comerciantes. Podría decirse que esto fue algo lógico dado que la principal actividad del puerto era el comercio, pero durante la época federal no se registra una participación tan activa de los comerciantes en el Ayuntamiento. Estos datos se pueden cotejar en Zanolli, "Liberalismo", 1989, pp. 322-330 y en las listas de personas que compusieron el Cabildo de Campeche durante los años mencionados, que presenta Alcocer, Historia, 1991, pp. 69-71.

${ }^{25}$ CAlHY, manuscritos, Acta de cabildo núm 22, 1830-1831, foja 1-1v. 
ser un gobierno democrático y conforme a la división de poderes. Aunque esta división fue muy sui generis.

No quedaba otro camino que demostrar la legalidad del gobierno, probar que el régimen era representante de la voluntad del pueblo yucateco y que había cedido sus derechos en las elecciones. La necesidad de crear un órgano legislativo para formar un proyecto de gobierno llevó a convocar al sufragio de los ciudadanos y a constituir una asamblea reunida en el pueblo de Bécal, llamada "Junta de Bécal".

\section{EL PROCESO ELECTORAL Y LOS ELECTORES DE LA JUNTA DE BÉCAL}

El 25 de febrero de 1830, José Segundo Carvajal convocaba a elecciones; el motivo aparente era una conciliación con el gobierno general. Se convocó a elegir representantes de partido que, conjuntamente con los militares, "puedan hacer por Yucatán cuanto convenga a sus verdaderos intereses". 26

La fórmula para elegir representantes fue a través de dos niveles: las juntas de parroquia y las juntas de partido. En las primeras se convocaba a todos los ciudadanos en el goce de sus derechos a reunirse en su parroquia. El pleno de la parroquia debía ser presidido por los miembros del ayuntamiento, es decir, alcaldes y regidores, o en su defecto por los jueces de paz y alcaldes auxiliares. De todos los votantes se elegían, por mayoría absoluta, dos escrutadores y dos secretarios, que junto con el presidente conformaban la junta rectora. ${ }^{27}$

${ }^{26}$ Ibid., Impresos, C. III-1823, doc. 048.

${ }^{27}$ lbid.
Los electores parroquiales pasaban a la cabecera de partido, allí el pleno era presidido por los jefes políticos subalternos, casi todos militares. Las decisiones de las juntas rectoras parroquiales y de partido tenían un carácter de inapelables, de ahí la importancia de ser controladas por los partidarios del régimen.

No hubo cambios en cuanto al número de electores parroquiales; el clecreto del 25 de febrero de 1830 decía: "como se ha practicado últimamente". Esto quiere decir que correspondía un elector por cada 1000 habitantes y dos por 1500 y así sucesivamente. ${ }^{28}$ En cambio, para los electores de partido sí se designó el número de representantes; fueron convocados 43 electores para la Junta Provincial de Bécal, que se reunirían con 30 oficiales militares (véase cuadro 1 ).

Resalta la apertura en el requisito para ocupar el cargo de representante de partido que hace recordar la Constitución gaditana: 29 "la elección se hará en sujetos

${ }^{28}$ Véase el decreto sobre elecciones a diputados al Congreso general dado en 1826, en CAHY, manuscritos, Documentos encuadernados, núm. 135, Decretos del Congreso del Estado y del Ayuntamiento, Mérida, 1826, fs. 7-8. O bien, consultar la Constitución yucateca de 1825, Yucatán, 1989), cap. IX, pp. 11-14.

${ }^{29}$ Efectivamente, desde la promulgación de la Constitución gaditana eran españoles "todos los hombres libres, nacidos y avecinados en los clominios de las Españas y los hijos". Pero no todos los españoles tenían la ciudadanía, sino "aquellos españoles que por ambas líneas traen su origen de los dominios españoles de ambos hemisferios, y están avecinados en cualquier pueblo de los mismos dominios" y que tenían un oficio o modo de vivir conocido. La ciudadanía se extendió hacia los indígenas, que podían participar en espacios políticos antes cerrados para ellos. En el caso de los extranjeros, primero tenían que pedir 


\section{SECUENCIA}

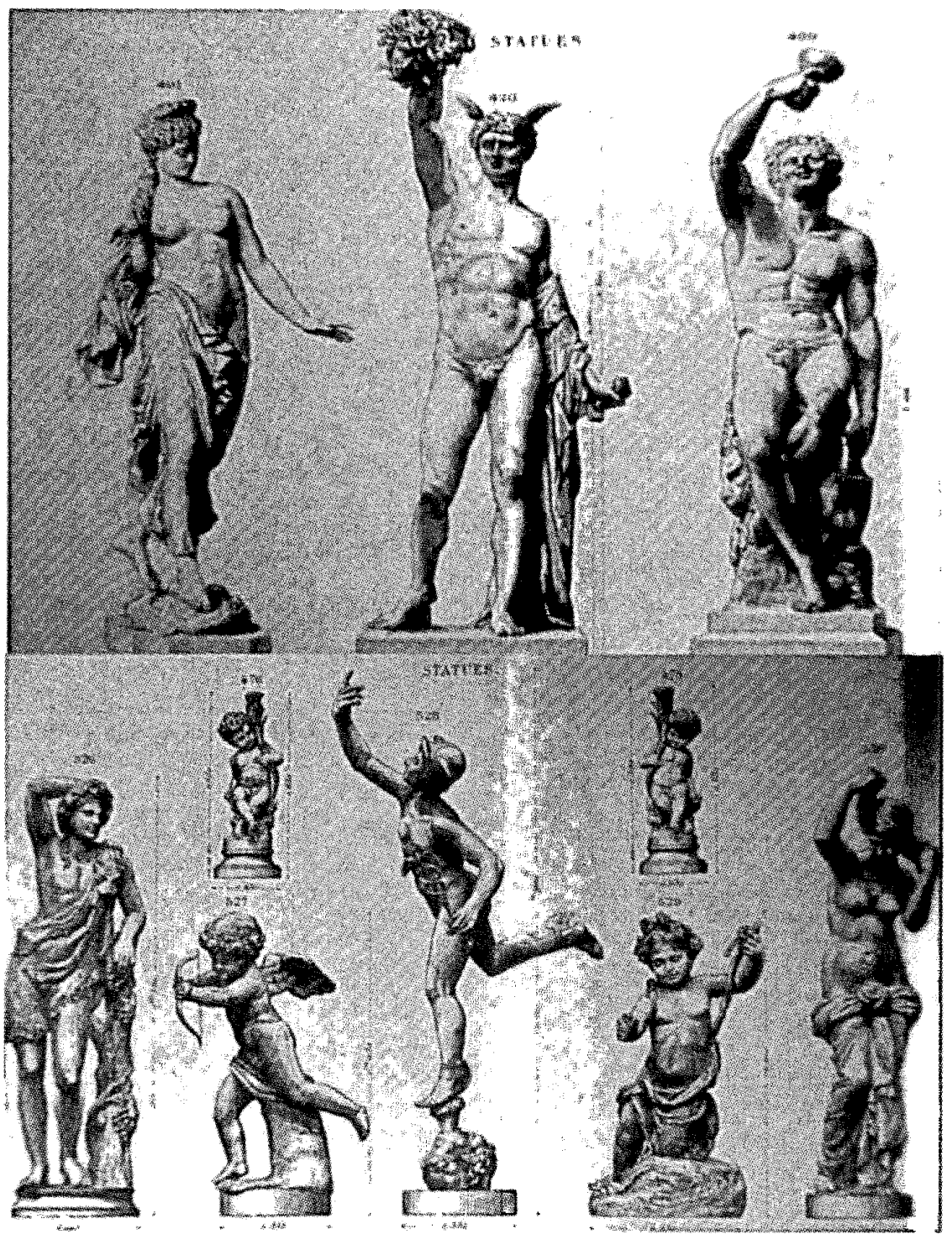




\section{Cuadro 1}

\begin{tabular}{lr}
\multicolumn{1}{c}{ Partido } & Represent \\
Izamal & 4 \\
Valladolid & 4 \\
Peto & 4 \\
Tekax & 3 \\
Sotuta & 3 \\
Teabo & 3 \\
Mérida & 3 \\
Hunucmá & 3 \\
Hecelchakán & 3 \\
Campeche & 3 \\
Seybaplaya & 3 \\
Tizimín & 3 \\
Carmen & 2 \\
Bacalar & 2 \\
Total & 43
\end{tabular}

Fuente: CAIHY, manuscritos, impresos, c. III, 1823 , doc. 048,1830 .

a las Cortes una carta de naturalización y luego la ciudadanía, pero antes debían demostrar que tenían un trabajo respetable o modo de vivir conocido.

El concepto de ciudadanía gaditana llevaba elementos del antiguo régimen al limitar a las personas que no eran consideradas buenos "vecinos". Pero a la vez se empezaba a separar de este término cuando en lugar de estatus, prestigio y riqueza de los habitantes, se anteponían a la naturaleza o al nacimiento el mérito y un modo decente de qué vivir. La Constitución de 1812 en este sentido incorporaba principios democráticos y modernos a la vida del imperio.

Para elegir a los diputados a Cortes se seguía un proceso dividido en tres niveles: 1) las juntas de parroquia, que constaban de dos partes, la elección de once personas, que recibían el nombre de compromisarios, por cada elector de parroquia a nombrar y la selección de los electores parroquiales. 2) Los electores de partoquia que se reunían en la cabecera de partido para escoger a los representantes del mismo, de acuerdo al censo, y 3) la reunión de los electores de partido en la capital de provincia para elegir al diputado o diputados a Cortes. de conocido mérito, ilustración y bienes, debiendo ser uno por lo menos del partido que elige". ${ }^{30}$ Esto es destacable porque en la Constitución yucateca de 1825 se establece: ser propietario con una posesión u oficio que no fuera menor de 200 pesos. ${ }^{31}$ La actitud del nuevo gobierno,

Salvo las castas, los sirvientes domésticos, las personas que no tuvieran oficio o modo conocido de vivir, los juzgados criminalmente y los defraudadores del estado, los cuales tenían suspendidos sus derechos de ciudadanía, todos los ciudadanos avecindados participarían en las elecciones parroquiales.

En general, hasta los electores de provincia no se pedía ningún requisito especial, salvo tener oficio $y$ modo de vivir respetable, pero para ser diputado a Cortes sí se necesitaba tener una renta anual proporcionada, procedente de bienes propios, saber leer y escribir, no ser extranjero y ser natural, vecino y ciudadano de las Españas. Los electos podían pertenecer a cualquier estado seglar o eclesiástico. Los datos sobre la Constitución de Cádiz se pueden consultar en Tena, Leyes, 1967, pp. 62-73.

${ }^{30}$ CAIHY, manuscritos, Impresos, c. III-1823, documento 048, 1830.

${ }^{31}$ La Constitución de 1825 hacía yucatecos a todos los nacidos y avecindados en el territorio del estado, a los extranjeros que hubieran obtenido su carta de naturalización y a los esclavos existentes en la entidad que habían obtenido su libertad. La ciudadanía se extendía a todos los yucatecos mayores de 21 y 18 años siendo casados, que tuvieran un oficio o modo de vivir conocido. Al igual que en la Constitución de Cádiz, no poseían la ciudadanía los que no tuvieran trabajo y modo de vida reconocido; estuvieran procesados criminalmente o fueran sirvientes domésticos. A partir de 1835 era indispensable saber leer y escribir y, como requisito nuevo, alistarse en la milicia local.

Al igual que en la Constitución gaditana, la ciudadanía estaba reservada para los "mejores vecinos", quienes se movían en los espacios políticos. En este sentido seguían perviviendo elementos del antiguo régimen, pero continuaba con la incipiente democratización al no imponer diferencias raciales y la riqueza para que los habitantes "honrados y decentes" ostentaran la ciudadanía. 
en este primer momento, puede explicarse en el sentido de que le era necesario sondear la participación de la ciudadanía, además de atraerlos a su causa. Si bien muchos de los cargos públicos habían sido ocupados por partidarios de los derrocadores, aún no se tenía un control certero del grueso de la población y la ciudadanía, ni se sabía de sus orientaciones políticas.

No hubo en este primer momento en el ámbito oficial, que no en la praxis, diferenciación entre ciudadanos "aristócratas" y "comunes". Por el momento interesaba a Carvajal, al menos en comunicaciones oficiales, tener simpatizantes, gente que pudiera darle el carácter de legal al régimen y afirmarlo en una situación política estable. Como se puede notar en un comunicado dado en Campeche al Ayuntamiento de Mérida, con motivo del decreto del 25 de febrero de 1830 :

y le recomiendo eficazmente [alcalde] procure q. en las juntas electorales se instruyan

Las fórmulas para elegir diputados al Congreso local, gobernador, vicegobernador y diputados al Congreso general, estaban basadas en la normativa gaditana, excepto que en las juntas de parroquia se eliminaba el nombramiento de los compromisarios. Pero, para ser elector de parroquia y de partido, ahora se pedía lo siguiente: saber leer y escribir, vivir por lo menos un año en el lugar, tener una renta permanente, profesión o industria productiva, que por notoriedad no fuera menor de 200 pesos (art. 37).

Para llegar a cargos públicos, la situación era más estricta: para ser diputado local se necesitaba poseer "una propiedad territorial de 2000 pesos o una renta permanente, o un ejercicio, profesión o industria productiva equivalente a 400 pesos anuales." Para gobernador, se necesitaba tener una "propiedad territorial de 4000 pesos, o una renta permanente, $o$ un ejercicio, profesión o industria productiva, equivalente a 800 anuales". Yucatán, 1989, pp. 8, 10-13. los C.C. del interanzantismo [sic] objeto de la junta gral. a fin de que la elección recaiga en personas capaces de desempeñar tan delicado encargo con la eficacia y circunspección q. se requiere [en] tan difíciles circunstancias. La junta gral. puede hacer mucho bien a Yucatán así como mucho mal: es preciso pues que se componga de personas de ilustración y a quienes animen los mejores sentimientos a favor de los intereses de su patria. $^{32}$

Ancona ha señalado que los militares estaban un tanto a la expectativa, desconfiados de lo que pudiera pasar en las elecciones, por eso a la junta de Bécal este grupo mandó a 30 representantes. El mismo autor dice que fue una medida inútil, porque en las elecciones sólo se apuntaron candidatos partidarios al régimen. ${ }^{33} \mathrm{Sin}$ embargo, las juntas de partido nos muestran que, a pesar de la aparente apertura del gobierno golpista, no dejaron de tomar sus precauciones. Los militares controlaron los niveles de votación, principalmente las juntas de partido, e incluso muchos de los electos eran oficiales del ejército. También funcionarios del nuevo gobierno, representantes del Ayuntamiento de Mérida y gente que había manifestado su adhesión al centralismo, fueron nombrados para representar a los partidos.

De los catorce partidos que elegirían representantes a la junta de Bécal, tenemos información de once, ${ }^{34}$ sin incluir

${ }^{32} \mathrm{CAIHY}$, manuscritos. Documentos encuadernados, núm. 64, Documentos varios del Ayuntamiento: correspondencia militar, política y de Hacienda del Gobierno de Yucatán, 1830, fs. 13-14.

33 Ancona, Historia, 1978, t. III, pp. 329-330.

34 AGEY, fondo Poder ejecutivo, ramo Gobernación, 1830, vol. 2, exps. del 19 al 29. 
los partidos de Mérida, Campeche y Hecelchakán:

Partido de la Isla de Carmen: ${ }^{35}$ Sebastián Peón y Juan Bautista Requena.

Partido de San Felipe Bacalar: ${ }^{36}$ José Luis de Meléndez y Arcadio Quijano.

Partido de Valladolid: ${ }^{37}$ Pedro de Baranda, Roberto Yldenfoso Rivas, Gregorio Cantón, Jacobo Machado.

Partido de Teabo: ${ }^{38}$ Francisco Coello, Andrés María Maldonado y José Cosgaya.

Partido de Tizimín: ${ }^{39}$ José Antonio García, José Cruz Villamil y José Manuel Peón.

Partido de Sotuta: ${ }^{40}$ Policarpo de Echánove, Manuel José Pardio y José Manuel Berzunsa.

Partido del Camino Real Bajo (Hunucmá): ${ }^{41}$ Ygnacio Manzanilla, Antonio Morales y Miguel Cámara.

Partido de Seybaplaya: ${ }^{42}$ Eulogio Rosado y José Ordaz.

Partido de Sierra Alta (Tekax): ${ }^{43}$ Ygnacio Machado, Lorenzo Peón y Manuel Castellanos.

Partido de Izamal: ${ }^{44}$ Pedro de Souza, Manuel Ponse, José Silvestre Dondé y Pedro Ruiz.

Partido de Beneficios Altos (Peto): ${ }^{45}$ Wenceslao Alpuche, Pedro Elizalde, Antonio Fajardo y Vicente Yenro.

\footnotetext{
${ }^{35}$ Ibid., exp. 19.

${ }^{36} \mathrm{Ibid}$, exp. 20.

${ }^{37} \mathrm{Ibid}$., exp. 21.

${ }^{38}$ Ibid., exp. 22.

39 Ibid., exp. 23.

${ }^{40}$ Ibid., exp. 24

41 Ibid., exp. 25.

42 Ibid., exp. 26.

$4.3 \mathrm{lbid}$., exp. 27.

${ }^{44}$ Ibid., exp. 28.

is lbid., exp. 29.
}

Es notable la presencia de militares, eclesiásticos y miembros del Cabildo de Mérida como representantes de partido. ${ }^{46}$ De los 34 representantes, podemos identificar a los militares: Eulogio Rosado (Seybaplaya), Pedro Baranda (Valladolid), José Luis de Meléndez (Bacalar), entre otros. ${ }^{47}$

${ }^{46}$ Los capitulares de Mérida fueron propuestos como representantes de partido donde tenían sus propiedades, como el caso de José de la Cruz Villamil, alcalde tercero y electo por el partido de Tizimín. Los alcaldes primero y segundo, Pedro Elizalde y Vicente Yenro, salieron nombrados representantes por Peto, y José María Peón, síndico primero, por Tizimín. Los nombres de los personajes mencionadus se pueden cotejar en CAIHY, manuscritos, Acta de cabildo núm. 22, 1830-1831. Destaca la selección de representantes de los partidos de Tizimín y Beneficios Altos (Peto). En el primero, dos de los electos eran capitulares del cabildo meridano y el otro puesto recayó en un cura, arriba mencionado. En este partido se notó una activa participación de sacerdotes, incluso uno de ellos, José María Domínguez de Espita, manifestó que "para el sostenimiento [del sistema central] si fuese necesario ofrecía su persona y bienes, cuya generosa oferta secundaron los demás electores". En lo que respecta a Peto, dos de los cuatro representantes eran del Ayuntamiento de Mérida y los otros dos restantes ya habían manifestado su fervor al centralismo: Wenceslao Alpuche y Antonio Fajardo. Por otra parte, en el partido de Sierra Alta, Tekax, fue electo el destacado camarillero y comerciante Lorenzo Peón, miembro del grupo encabezado por Pedro José Guzmán. Agiry, fondo Poder ejecutivo, ramo Gobernación, 1830, vol. 2, exp. 23; Zanolli, "Liberalismo", 1989, pp. 405-418.

${ }^{47}$ En los partidos periféricos y con escasa población, el dominio de los militares, funcionarios del gobierno y sacerdotes se hizo más evidente. La activa participación de estas personas se puede explicar, en el caso de los sacerdotes, porque en las elecciones parroquiales ellos eran las personas con mayores recursos económicos y de prestigio de la población, por ejemplo el cura del pequeño poblado de Chicbul, partido de Seybaplaya. Tres de los diez votantes de aquel partido pertenecían al clero. En el Carmen, la junta del 
Eclesiásticos como Jacobo Maldonado, cura de Tunkás, partido de Valladolid; por Tizimín José Antonio García; por Sotuta, el párroco de la cabecera del mismo nombre Manuel José Pardio, y de Tixcacal, José María Bersunza; Ygnacio Barrera (presbítero de Chicbul, partido de Seybaplaya), y José Silvestre Dondé por Izamal.

Llama la atención que al partido de Valladolid, de 60 electores parroquiales, se le hayan concedido cuatro representantes de partido, mientras a Tekax, de 61 sólo tres. Al parecer, en esta distribución de electores lo que importaba en muchos casos era el peso político de las cabeceras, lo que fue notable en los casos de los partidos de Mérida y Campeche (en éste el partido era únicamente la ciudad), a los que se les concedieron tres electores, al igual que las zonas más pobladas, como fueron la Sierra Alta (Tekax) y Sotuta, por ejemplo. ${ }^{48}$

parcido presidida por el comandante de armas de la plaza, José del Rosario Gil, resultó electa por seis votantes: el administrador de la Hacienda pública y secretario interino del gobierno Sebastián Peón, y el subdelegado y juez de primera instancia Juan Bautista Requena. En Bacalar, la junta estaba compuesta por tres electores; el citado José Luis de Meléndez que era oficial militar fue electo como presidente, y Arcadio Quijano como recaudador de las rentas decimales.

${ }^{48}$ Salvador Rodríguez señala que desgraciadamente no hay datos de Mérida y Campeche en el censo inédito de 1821 , pero con base en un cálculo aproximado hecho por investigadores del CINVESTAV y la Facultad de Matemáticas de la UADY, la población de Campeche en el año del censo era de 18310 habitantes y la de Mérida y su comarca, de 30803 . Véase Rodríguez, Geografía, 1985, t. I, pp. 29, $90-$ 113 , en especial el cuadro IX. Nosotros poseemos el dato de que en la sesión del cabildo emeritense de 3 de julio de 1823, el regidor Tomás Luján solicitó ma-
Las fórmulas para llevar a cabo la elección no tuvieron una normativa fija. Algunos partidos se basaron en la Constitución y nombraron tres escrutadores y un secretario que, junto con el presidente, verificarían la legalidad de los electores parroquiales, a la vez, una comisión de tres personas revisaría sus documentos. En otros partidos, los votantes siguieron el decreto del 25 de febrero de 1830 y se nombraron dos escrutadores y dos secretarios. En el partido de Izamal, fue seleccionado un suplente de los cuatro representantes propietarios.

\section{EL PROYECTO DE GOBIERNO CENTRALISTA PLANTEADO POR LA JUNTA DE BECAL: EL ACTA INSTITUYENTE}

Un gobierno débil, sin las energías suficientes para pedir a la federación la derogación de las pesadas cargas fiscales; un régimen excluyente, representativo de una facción y no de los intereses de los

yor número de electores para Mérida debido a que su población ascendía a 38 o 39000 almas. CAlHY, manuscritos, Acta de cabildo núm. 18. Para el caso de la ciudad de Campeche, contamos también con una exposición de José Segundo Carvajal, elector por Campeche, pidiendo en 1820 que el puerto tuviera una representación permanente en la Diputación Provincial por su ilustración, riqueza, prosperidad y por superar los 20000 habitantes. AGEY, fondo Colonial, ramo Diputación Provincial, 1820, vol. 1, exp. 13. De cualquier forma a Mérida le correspondían a lo más to electores parroquiales, número mucho menor que el de Tekax arriba mencionado, y a Campeche 19 electores, ya que su población -por tomarse en cuenta sólo la ciudad- era menor que la de partidos como Hunucmá o Hecelchakán. Véase Rodríguez, Geografía, 1985, t. I. 
yucatecos, que no había podido proteger los sagrados valores de la libertad, seguridad y derecho a la propiedad de los ciudadanos. En suma, un gobierno y un proyecto fracasado, incapaz de procurar la felicidad de los habitantes de la península, fueron las razones en las que se fundamentó el pronunciamiento de José Segundo Carvajal en contra de José Tiburcio López, en noviembre de 1829:

Una administración sin sistema, apática e indolente, probó que el gobierno adoptado por los mexicanos no se había calculado sobre el genio ni sobre las costumbres, y que este genio, estas costumbres, estas ideas dominantes no eran la salvaguardia de las instituciones, que se sostenían por el interés de los unos y la indiferencia de los otros. De aquí resultó que unas leyes sin arraigo, sin energía y sin sistema hicieron brotar las facciones, y que a la vez se sobrepusieron a las leyes y al gobierno, aboliendo de hecho la libertad y anulando al mismo tiempo la seguridad y la propiedad [...] El estado interior de la península no era más feliz en lo particular que el de la república en general [...] tampoco tenía una administración, sino un partido dominante que trabajaba sólo por sí y no por los pueblos. Yucatán había demostrado que el sistema mercantil que se adoptó para toda la república no podía comprenderlo sin la ruina total de la península. ${ }^{49}$

Es claro observar en el manifiesto que "los centralistas, bajo la influencia de Montesquieu, resolvían el problema de las costumbres y leyes afirmando que las primeras determinaban a las segundas, antes de que las leyes lo hicieran con las cos-

\footnotetext{
49 Ancona, Historia, 1978, t. III, pp. 327-8.
}

tumbres". ${ }^{50} \mathrm{O}$ sea, ninguna ley, ya sea general o estatal, antes de las particularidades y forma de vida de los yucatecos. Sin embargo, es más notoria la influencia de Locke en este pronunciamiento de Carvajal, pues el régimen lopista no supo cuidar los derechos naturales de los yucatecos: seguridad, libertad y propiedad. Por lo tanto, la sociedad civil podía y debía clamar por la reparación de aquel agravio, rompiendo el pacto establecido con el gobierno y derrocándolo. ${ }^{51}$

La mención de un gobierno que desatendía la felicidad de los pueblos, permite también observar los matices jusnaturalis$\operatorname{tas}^{52}$ que se mezclaban con las ideas del liberalismo inglés individualista o burgués. ${ }^{53}$

${ }^{50}$ Jardin, Historia, 1989, p. 67.

${ }^{51}$ Locke, Ensayo, 1976, caps. II-V y VII-VIII.

52 "Annino, siguiendo una reflexión de O'Gorman sobre las supervivencias novohispanas en el México independiente, ha desarrollado la idea de la presencia del pensamiento español del derecho natural en el discurso liberal temprano. El jusnaturalismo se entendería como la existencia de un ordenamiento social preexistente al pacto social que permanece cuando éste se ha roto. La idea del estado natural justificaría los diversos pronunciamientos". Castillo y Chi, "Pronunciamiento", 1998, p. 19. El levantamiento en España tras la invasión napoleónica también se justificó con el jusnaturalismo, la soberanía regresó al pueblo para luchar contra el tirano usurpador que atentaba contra el derecho natural del mismo. En el México independiente, en el federalismo y en el centralismo, los pronunciamientos se van a justificar por este concepto, sólo que la modalidad variará de acuerdo con la experiencia o la visión latinoamericana: se tratará de preservar la felicidad y los derechos de los pueblos. Se pueden consultar los trabajos de Annino para abundar más sobre el término jusnaturalista. Annino, "Nuevas", 1995, pp. 68-74, y "Ciudadanía", 1999, pp. 62-93.

${ }^{53}$ El liberalismo burgués surgió contra el autoritarismo del Estado-monarca defendiendo los derechos 
Coincidimos con Zanolli en el sentido de que el propósito de los camarilleros, en gran parte ideólogos de los planteamientos centralistas, era en buena medida

ver solucionados los problemas por los que había abogado desde finales de la colonia [el gobierno yucateco], que en 1823 se habían traducido en su adhesión al federalismo, y que el gobierno de López no había podido resolver. Es decir, los motivos por los que ahora se adherían al centralismo no eran distintos de los que los habían llevado al federalismo, sino los mismos. ${ }^{54}$

El mismo José Segundo Carvajal fue firmante del acta de 1823, en la cual Yucatán se integraba al gobierno general siempre y cuando éste adoptara el federalismo y respetara las peculiaridades económicas del lugar. Esto también puede explicar la activa participación de los comerciantes en el nuevo régimen de 1829.5

individuales. Después de la revolución francesa y su interludio de dictadura jacobina, "el liberalismo burgués había combatido el privilegio aristocrático pero no estaba dispuesto a aceptar una ciudadanía amplia y sus consecuencias democráticas. Por tanto la policidad liberal adoptó lo que el gran teórico liberal de comienzos del siglo xIx, Bejamín Constant, llamó le juste milieu [el justo medio]: un centro político, a medio camino entre el absolutismo y la nueva democracia. El liberalismo pasó a ser la doctrina de la monarquía limitada y un gobierno del pueblo igualmente limitado, puesto que el voto y la representación siguieron restringidos a una ciudadanía de ingresos elevados [...] Sin embargo, esa policidad burguesa no era sino una forma transitoria, que pronto sería reemplazada por el sufragio masculino universal." Merquior, Liberalismo, 1993, pp. 16-17.

54 Zanolli, "Liberalismo", 1989, p. 409.

${ }^{55}$ Hasta aquí estamos de acuerdo con Zanolli en el sentido de que preocupaban a los políticos yucatecos las condiciones con las que Yucatán se unió a
Los autores decimonónicos criticaron duramente el pronunciamiento por el centralismo, lo relacionaron con el conservadurismo y lo catalogaron de ser un movimiento retrógrado. Pero el proyecto de gobierno centralista lleva en sí mucho de la ideología liberal, aunque aplicada de manera diferente, como discutiremos a continuación.

\section{LOS CENTRALISTAS SIGUEN EL PLANTEAMIENTO DE SOBERANÍA DE LOS FEDERALISTAS YUCATECOS}

La Junta de Bécal ${ }^{56}$ emitió un pronunciamiento en el cual justificaba y planteaba

México. Sin embargo, no coincidimos con la autora, quien a nuestro parecer exalta demasiado el papel liberal de los centralistas en pro del pueblo y en su planteamiento de que el gobierno de López Constante era indiferente a la situación del comercio y de la economía yucateca, pues como ya vimos en páginas anteriores, sí se enfrentó al gobierno general, pero no obtuvo resultados. Estos datos también se pueden consultar en los libros decimonónicos de historia de Yucatán. Tampoco apoyamos la suposición de que los camarilleros y centralistas nunca dejaron de ser auténticos federalistas. Realmente se creyó en el proyecto de gobierno centralista, que aunque nacido de las necesidades de Yucatán, adquirió un matiz diferente del sistema de gobierno federal antes planteado, que discutiremos a lo largo de este trabajo. Por lo tanto, el enfrentamiento entre José Tiburcio López, líder de la Liga, y Pedro José Guzmán, traspasó la esfera de lo económico, a lo que se limita la autora, hasta llegar al nivel ideológico desembocando en el enfrentamiento de proyectos de gobierno centralista y federalista, que no liberal y conservador, $y$ dejando atrás las antiguas clisputas "Liga" vs. "Camarilla". Para leer los planteamicntos de la historiadora citada, véase ibid., pp. 405-418.

${ }^{56}$ Hemos encontrado los planteamientos de la reunión de Bécal, llamada acta constitutiva, en el diario La Concordia Yucateca, periódico liberal de Méricla de Yucatán, 29 de mayo de 1830, Mérida, pp. 1-4. 
la forma de gobierno centralista. En primera instancia, se aclaraba que de ninguna manera el pronunciamiento era un movimiento reaccionario:

el pronunciamiento del ejército de esta provincia por el sistema de república central, representativa popular bajo las bases de la división de poderes, se considera justo y patriótico, y es en el todo conforme a la voluntad general, y conveniente a los intereses de la nación. ${ }^{57}$

Éste fue el primer artículo del acta instituyente emanada de la mencionada junta, y se nota la ideología liberal, basada en los planteamientos de Montesquieu sobre la división de poderes. Así expresado, el pronunciamiento también tiene un carácter legítimo, pues nació de la voluntad del pueblo y la república centralista era la forma de gobierno más apropiada para la nación.

Lo anterior da pie a las propuestas de los siguientes artículos: $\mathrm{el}$ art. $2^{\circ}$ aclaraba que Yucatán seguía siendo parte de la república mexicana y defendería la independencia; $3^{\circ}$, el gobierno de Yucatán reconocería al general, cuando éste abrazara el sistema central; $4^{\circ}$, los supremos poderes ratificarían los actos de los pronunciados desde el 5 de noviembre de $1829 ; 5^{\circ}$ al Congreso general sólo se le reconocía el carácter de convocante y pedía su renovación en ambas cámaras por funcionarios centralistas; $6^{\circ}$, mientras no se publicara una constitución centralista, las disposiciones del gobierno general quedaban sin efecto en la península.

Sobre estos artículos, Eligio Ancona, con cierta mofa, dice:

${ }^{57}$ Ibid., p. 1.
Si en virtud de la marcha tortuosa que seguía la república, Carvajal y sus subalternos hubiesen proclamado la independencia de Yucatán, habría sido, si no más disculpable, al menos más lógico su levantamiento. No es inverosímil suponer que este proyecto surgió entre los principales jefes pronunciados; pero no pudieron llevarlo a cabo porque existía en Campeche un batallón mexicano que indudablemente se habría opuesto a seguir en esta senda a los yucatecos. ${ }^{58}$

Molina Solís, dice que los militares de la península posiblemente fueron motivados por sus similares del resto del país, y al creer tener su apoyo iban tan lejos en sus proclamas. Sin descartar esta razón, preferimos buscar los fundamentos de la petición del nuevo régimen en la misma Constitución federal yucateca de 1825 . Ya lo hemos mencionado en páginas anteriores, el concepto de soberanía estatal y de nación se acercaba a un autonomismo confederal, o bien, se debía a la visión contractual de soberanía en contraposición a una postura unitaria. Citemos en estos renglones el artículo 76: el cuerpo legislativo estatal puede "pedir motivadamente al Congreso general la derogación, suspensión o modificación de la leyes generales de la Unión, que por circunstancias peculiares ofendan los derechos inmanentes del Estado".59

Es importante hacer hincapié en que éste fue un momento coyuntural, se trataba de presionar al gobierno general para que aceptara el centralismo, por eso los tintes del centralismo yucateco que resultan irónicos con el deseo del control

${ }^{58}$ Ancona, Historia, 1978, t. III, p. 328.

59 Yucatán, 1989, cap. IX, art. 76, apartado $2^{\circ}$, p. 16. 
de la soberanía de los pueblos dentro del estado. Como veremos más adelante, los centralistas yucatecos fueron definiendo su proyecto de gobierno centralizante y unitario, combatiendo al contractualismo.

\section{LA ORGANIZACIÓN DE LOS PODERES Y SUS BASES IDEOLÓGICAS}

La junta de Bécal era una especie de cuerpo legislativo extraordinario con el fin de crear un nuevo proyecto de gobierno. La prensa en la capital de la república atacó duramente las irregularidades con las que fue conformada la junta, empezando con el hecho de haber sido convocada por los golpistas, no tener representación popular y caer en la contradicción de ser una especie de Congreso, cuando de esto rehuían los centralistas.

Pero los partidarios del centralismo se defendieron diciendo que era lógico que José Segundo Carvajal convocara a elecciones para la Junta de Bécal, porque no lo podían hacer los destituidos. Además, proclamaban que no era un Congreso la citada reunión sino una representación popular. Es decir, que se trataba de poner a la junta como una representación de la sociedad civil, necesaria para establecer un nuevo pacto y dar marcha al proyecto del gobierno centralista. Lo que se nota en la siguiente refutación:

proclamar la destrucción de los congresitos ordinarios, y plantear los extraordinarios [...] sería incurrir en una contradicción ridícula, como está sucediendo en toda la nación con ciertos y determinados negocios. Era del caso, sin embargo, reunir una representación popular para saber el voto explícito de los yucatecos; y se consiguió ciertamente por medio de elecciones, las más libres y populares que se han conocido en toda la nación. ${ }^{60}$

El rechazo a la conformación de congresos estaba fundamentado en las razones citadas arriba y que recalcaron los defensores del centralismo:

más que a los animales ponzoñosos debe temerse a los congresitos desmoralizados como el que existía en Yucatán. Constituidos en legisladores absolutos a título de regentear la soberanía del estado, no hacían más que lo que les daba la gana, aunque fuese con perjuicio del género humano. Creyéndose reguladores de la opinión, la dirigían siempre a sus miras, sin demorarse en los medios. He aquí en suma compendiados los trabajos de los congresitos formados por lo regular por hombres inútiles y sometidos a los intereses del gobernador. ${ }^{61}$

La ineficacia de los congresos era el motivo para abolirlos, lo que no significaba la eliminación del poder legislativo, sino su sustitución por un Consejo provincial. No obstante tener forma de un Senado, prácticamente sus funciones se reducían a verificar la aplicación de las leyes y el acta de Bécal, así como servir de consulta y emitir dictámenes sobre asuntos del jefe político provisional. Eso sí, el ejecutivo no podía hacer reformas en ninguno de los ramos de la administración pública "sin el indispensable acuerdo del Consejo provincial". ${ }^{62}$ Lo que significaba que el ejecutivo tenía que trabajar

${ }^{\circ}$ La Concordia Yucateca, periódico liberal de Mérida de Yucatán, 29 de mayo de 1830, Mérida, p. 3.

${ }^{61}$ Ibid., p. 3.

${ }^{62}$ Ibid., p. 1. 
conjuntamente con este cuerpo en la dirección del nuevo proyecto de gobierno.

El Consejo Provincial no era sino una forma adaptada del Consejo de Estado gaditano ${ }^{63}$ de 40 individuos, impuesto al rey por las Cortes para la consulta de los asuntos de gobierno, sólo que más móvil y de mayor injerencia que aquél, pues dicho Consejo se conformaba por siete individuos propietarios e igual número de suplentes, nombrados por la Junta de Bécal. En lo esencial, ambos consejos tenían la particularidad de anteponer la prudencia a la fuerza del ejecutivo, por medio de los acuerdos que tomaban las dos instituciones.

Por otra parte, el resto de los poderes que conformaban el gobierno provisional eran el poder ejecutivo, que recaía en el jefe político y comandante general, y el judicial, en los Tribunales de Justicia. Es obvio que el poder ejecutivo era el que obtenía más atribuciones, pues le correspondía nombrar a los jueces de los supremos tribunales, a los empleados civiles, militares y religiosos, dirigir y hacer variaciones en la administración pública y también le estaba permitido emitir leyes. Esta última función fue duramente criticada por la prensa de la capital mexicana, pues se "ha hecho del jefe de la fuerza, el ejecutor de las leyes y el de legislador provisorio". Los partidarios del centralismo respondieron que "no solo sino con el indispensable acuerdo del consejo en el caso que la necesidad obligue a variar alguna ley". ${ }^{64}$

Sin embargo, las anteriores limitaciones no eran suficientes, como lo había señalado en su catecismo José María Luis

${ }^{63}$ Tena, Leyes, 1967, pp. 88-89.

${ }^{64}$ La Concordia Yucateca, periódico liberal de Mérida de Yucatán, 29 de mayo de 1830, Mérida, p. 3.
Mora, ${ }^{65}$ el ejecutivo era la fuerza y por lo tanto el más peligroso de los poderes si no tenía límites. Con la abolición del Congreso y sus funciones, entre ellas las facultades de las cámaras de Senadores y Diputados de formar causa contra el gobernador, no quedaba otro medio que delegar al poder judicial tal atribución y al Consejo Provincial. Con lo que el proyecto de gobierno centralista demostraría que no era despótico.

En efecto, la asamblea de Bécal había dispuesto "que para hacer efectiva con arreglo a las leyes la responsabilidad del jefe superior, deberán de preceder las calificaciones conformes del Consejo Provincial, y de un gran jurado compuesto de 25 individuos previamente insaculados". ${ }^{66}$ A pesar de que se mencionaba que el Consejo tomaba parte en la formación de causa contra el ejecutivo, los centralistas recalcaron más el papel del poder judicial. Así lo manifestó el mismo José Segundo Carvajal al Ayuntamiento de Mérida:

[En] el adjunto periódico se halla la lista de los señores que componen del gran jurado q. deben declarar con lugar a la formación de causa al jefe superior según el acta instituyente y espero del celo de vuestra señoría lo haga saber a los habitantes de este partido para que si algún ciudadano de él intente alguna acusación la dirija al E. consejo para q. éste obre según sus atribuciones. ${ }^{67}$

${ }^{65}$ Mora, "Catecismo", 1965 , p. 564.

${ }^{66}$ La Concordia Yucateca, periódico liberal de Mérida de Yucatán, 29 de mayo de 1830, Méricla, p. 2.

${ }^{67}$ CAIHY, manuscritos, Documentos encuadernados, núm. 64, Documentos varios del Ayuntamiento: correspondencia militar, política, del gobierno de Yucatán, 1830, f. 35. 


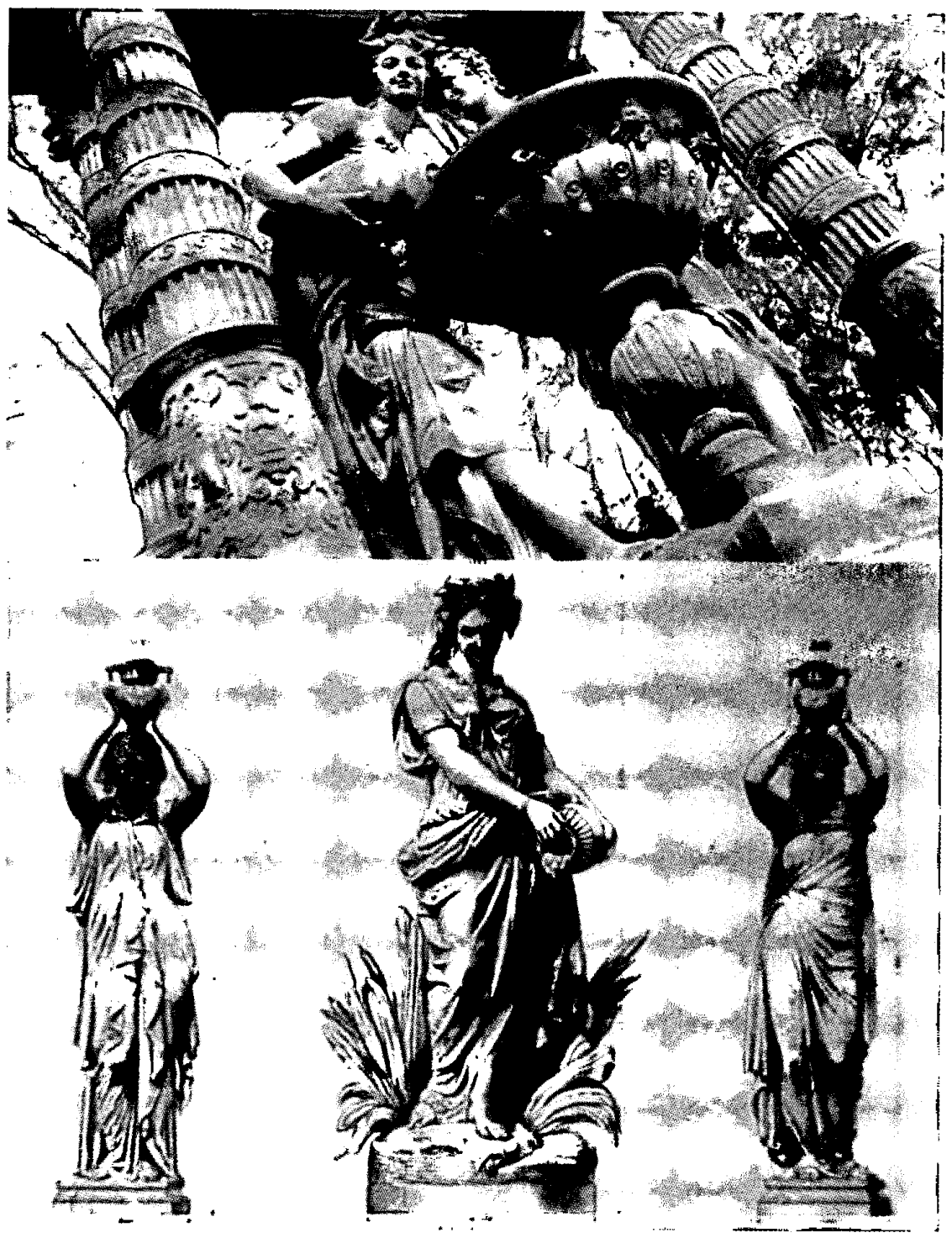


Siguiendo con el comunicado, es de notar que José Segundo Carvajal estaba plenamente consciente del poder que residía en su persona como ejecutivo, como la fuerza que debía limitarse, de acuerdo con la doctrina liberal:

Los dignos miembros de la augusta asamblea general conociendo lo peligroso que es el q. cualquier funcionario público se halle exento de responsabilidad alguna, han puesto barrera al poder que aunque se deposite en el hombre armado de los sentimientós y de las mejores intenciones, siempre debe temerse $\mathrm{q}$. degenere en arbitrariedades [...] no aspiro a otra satisfaccion q. el q. la época de mi mandaro esté marcada por la justicia y la beneficencia, mas soy un hombre y por consiguiente tengo pasiones y éstas pueden inducirme a errores que aunque involuntarios siempre son perjudiciales a los ciudadanos en general y en particular: así es que todo lo que sea garantías en favor de mis compatriotas linsojea mi alma [...] En este concepto reitero a vuestra señoría q. eficazmente emplee su celo para q. por su órgano sepan todos los habitantes de este partido el dro. q. les asiste de acusar al jefe superior y la obligación en q. éste se halla de responder ante la ley de su conducta. ${ }^{68}$

Nuevamente, Carvajal nos recuerda los planteamientos de Locke:

tengan presente que los monarcas absolutos son únicamente hombres. Si el poder civil ha de ser el remedio de los males que necesariamente se derivan de que los hombres sean jueces en sus propias causas [...] qué género de poder civil es aquel en que un hombre solo, que ejerce el mando sobre una

${ }^{68}$ Ibid., fs. 35-36v. multitud, goza de libertad de ser juez en su propia causa y en qué aventaja ese poder civil al estado de la naturaleza, pudiendo como puede ese hombre hacer a sus súbditos lo que más le acomode a su capricho sin la menor oposición o control de acjuellos que ejecutan ese capricho suyo. ¿Habrá que seguir a ese hombre en todo lo que hace, lo mismo si se equivoca o se deja llevar por su pasión? Los hombres no están obligados a portarse unos con otros de esa manera en el estado de la naturaleza, porque si quien juzga, juzga mal en su propio caso o en el de otro, es responsable de su mal juicio ante el resto del género humano. ${ }^{69}$

Si bien el gobernador intervendría directamente en la selección de los tres jueces que conformarían el Supremo Tribunal de Justicia, eligiéndolos de los nueve individuos propuestos por el Consejo Provincial, por su conocida "ilustración y bienes", no así los formadores del Gran Jurado y los tribunales de primera, segunda y tercera instancias, que eran los encargados de formar causa al ejecutivo. En este sentido, recalcamos el papel del poder judicial en el proyecto de gobierno de la Junta de Bécal, porque en teoría su desempeño era relativamente autónomo del ejecutivo y del legislativo.

A diferencia de lo señalado en la Constitución de 1825 , donde se marca que el Senado nombrará a los jueces de primera instancia, la Cámara de diputados a los

${ }^{69}$ Locke, Ensayo, 1976, p. 12. Locke también señala la necesidad de que entre el gobierno y el poder civil haya organismos como los cuerpos legislativos o magistrados nombrados por los mismos, para verificar que no se violen los derechos naturales de los hombres ni las leyes de las sociedades civiles, conservando la justicia. Ibid., caps. II, III y VII-XII. 
de segunda y tercera, y el gobernador a los restantes. En cambio, el acta instituyente de la Junta indicaba que para la elección de los 25 miembros del Gran Jurado, cada ayuntamiento de Yucatán debería proponer a 20 individuos; de todos los propuestos, el Consejo Provincial seleccionaría a 100; posteriormente, el jefe superior realizaría la insaculación o sorteo de los propuestos, de donde resultaría, por azar, el nombre de 25 individuos. $\mathrm{Si}$ el gobernador no verificara la insaculación, lo haría el alcalde del lugar sede del Consejo. De las 75 personas restantes, se sortearían quince más para conformar las salas de primera, segunda y tercera instancias, con igual número de integrantes. ${ }^{70}$

En suma, como ha señalado Josefina Vázquez, ${ }^{71}$ el gobierno general, bajo el centralismo, pretendía buscar mayor agilidad en la administración, aboliendo el Congreso y la figura del vicepresidente. Ideólogos del centralismo como Mariano de Cicero se ocuparon de criticar la Constitución de 1824 porque decían que el poder ejecutivo tenía insuficientes atribuciones para gobernar. ${ }^{72}$ Pero también era un doble juego, porque el ejecutivo concentraba mayor poder al eliminarse su contrapeso administrativo y legal. El único freno legal lo constituía el poder judicial, cuyas atribuciones no chocaban o coincidían con el gobernador, por remitirse sólo a la esfera de la justicia. Es importante destacar que este proyecto de gobierno yucateco se adelantaba varios años

${ }^{70}$ La Concordia Yucateca, periódico liberal de Mérida de Yucatán, 29 de mayo de 1830, Mérida, pp. 1-2.

${ }^{11}$ Vázquez, "México", 1995, p. 31, y "Difícil", 1994, p. 15.

${ }^{72}$ Campos, "Política", 1995, pp. 400-401. a las medidas similares tomadas por el gobierno general centralista de $1836 .^{73}$

Una vez que el proyecto de gobierno provisional estaba legalizado y adoptado por los cabildos de los pueblos, ${ }^{74}$ faltaba un detalle muy importante a tratar por el régimen de José Segundo Carvajal: el restablecimiento de las relaciones con el gobierno general. Para ello hubo de nombrarse nuevos diputados por Yucatán.

\section{LA JUNTA de CALKINí. El LIBERALISMO BURGUÉS INVADE EL PROCESO ELECTORAL}

Inmediatamente después de la promulgación del "acta instituyente de la Junta de Bécal", los ayuntamientos de los pueblos de Yucatán se apresuraron a adherirse al nuevo gobierno. Sintiéndose sólido y legalizado dictó medidas para controlar las

${ }^{73}$ Estamos en desacuerdo, por todo lo argumentado en pártafos arriba mencionados, con la idea de que el poder judicial fuera como un "Senado conservador", nombrado por el ejecutivo, como lo afirma Marco Bellingeri. Y discrepamos con dicho autor que señala al centralismo yucateco como netamente conservador o de retroceso, porque el jefe superior reunía el gobierno militar, político y de Hacienda, es decir, el proyecto de la Junta de Bécal preveía la unión de cargos ejecutivos, administrativos y militares de forma similar con la tradición de los últimos gobiernos españoles; pues arriba discutimos elementos liberales del movimiento de Carvajal. También, al menos en teoría, se planteaba al poder de la justicia sobre bases liberales. Véase Bellingeri, "Soberanía", 1995, pp. 84-85.

${ }^{74}$ Diversos pueblos de los diferentes partidos sancionaron lo dispuesto por la junta de Bécal; por ejemplo los de los partidos de Sotuta y Peto. Véase AGEY, fondo Poder ejecutivo, ramo Gobernación, 1830, vol. 2, expedientes del 30 al 46 . El tenor de las actas de adhesión fue la infelicidad que traía el sistema federal a los habitantes, arruinando la agricultura, el comercio por los gravosos impuestos y la encarnizada persecu- 
elecciones a diputados al Congreso de la Unión. Para tal fin, por medio del decreto del 22 de octubre de 1830 se citaba a una nueva Junta Provincial en diciembre del año cursante en el pueblo de Calkiní.

$\mathrm{Si}$, por su apertura, la convocatoria y los requisitos para ser representantes de los diversos niveles del proceso electoral a la asamblea de Bécal se parecían más a lo decretado por la Constitución de Cádiz, que a la Constitución yucateca de 1825 , la nueva normativa electoral cambiaba drásticamente al volverse más cerrada. Los citados actores políticos, al igual que habían hecho los centralistas con respecto al régimen anterior, se quejaban de estar representados por una facción.

Las fórmulas para llevar a cabo las elecciones de parroquia, de partido y de provincia no variaron mucho de las decretadas en 1826: 1) se nombrarían cuatro escrutadores y un secretario en todos los grados del proceso, quienes serían presididos por las máximas autoridades locales de los mismos. Éstos verificarían la legalidad de las elecciones y certificarían la validez de las actas levantadas $y$, a partir de las juntas de partido, una comisión de tres individuos, también nombrados, certificaría la legalidad de las actas de los escrutadores y secretarios. 2) El número de electores parroquiales sería de acuerdo con el censo de población: por cada 1000 habitantes se nombraría un elector, por 1500 dos, por 2500 tres y así sucesivamente; no obstante, en las poblaciones de 500 habitantes se elegiría un elector. ${ }^{75}$

ción de los hombres de bien. Todo esto había motivado al Ayuntamiento de Peto a unirse al centralismo. Ibid., exp. 46.

${ }^{75}$ Esta información está basada en el decreto expedido por José Segundo Carvajal, jefe superior de
Para el número de electores de partido se dispuso algo diferente a lo planteado por la convocatoria a la Junta de Bécal; por todos se llegaba al número de 35: Mérida, dos; Campeche, dos; Valladolid, cuatro; Izamal, cuatro; Peto, cuatro; Tekax, cuatro; Hecelchakán, tres; Sotuta, tres; Hunucmá, dos; Teabo, dos, Tizimín, dos; Seybaplaya, Carmen y Bacalar, uno por cada partido. ${ }^{76}$

Las innovaciones asentadas en el decreto del 22 de octubre implicaban la participación de los militares en las juntas de parroquia, junto con los demás ciudadanos, donde también podían ser propuestos como candidatos. Esto lo prohibía la Constitución de 1825 y el decreto de 29 de julio de 1826 (arts. 13 al 15). ${ }^{77}$ El principal requisito para poder ser representante en cualquiera de los tres niveles, fue el siguiente:

que los pueblos al hacer el nombramiento de los electores de partido, estén advertidos, no sólo que deben autorizarlos competentemente para el nombramiento de diputados, en sujetos que de modo inequívoco hayan dado pruebas de su adhesión al sistema central que feliz rige, sino también, para dar a éstos las instrucciones necesarias al mejor desempeño de su encargo, ciñéndose precisamente a las bases establecidas en los cuatro artículos del acta instituyente de Bécal. ${ }^{78}$

Yucatán, de las bases para elecciones, dado en Campeche, el 22 de octubre de 1830 en CAIHY, manuscritos, Impresos, c. JII-1823, doc. 056, 1830.

${ }^{76} \mathrm{Ibid}$.

${ }^{77}$ CAIHY, manuscritos. Documento encuadernado, núm. 135, fs. 7-8.

${ }^{78}$ CAIHY, manuscritos, Impresos, C. III-1823, doc. $056,1830$. 
En el decreto se puede observar la fuerte presencia del liberalismo individualista o de Constant en los requerimientos para representante en los tres niveles, es decir, la disposición de poner la propiedad y los bienes como medida para obtener los cargos más altos. Nuevamente las ideas de Constant, ${ }^{79}$ esta vez más que los de Locke, influyeron en los decretos de los centralistas como lo habían hecho en los federalistas, sólo que ahora eran más radicales. Lo que no es raro, dada la activa participación de los comerciantes, de los camarilleros y del grupo de propietarios.

De acuerdo con el decreto de 1830:

Art. 13. Para ser elector parroquial se requiere: $1^{\circ}$ Ser ciudadano en el ejercicio de sus derechos. $2^{\circ}$ Ser mayor de 25 años. $3^{\circ}$ Ser vecino del pueblo, con residencia a lo menos de un año. $4^{\circ}$ Saber leer y escribir. $5^{\circ}$ Tener una propiedad territorial, o renta permanente, o un ejercicio, profesión o industria productiva, que por notoriedad no baje de 200 pesos. ${ }^{80}$

${ }^{79}$ Constant argumentaba que la clase trabajadora no estaba capacitada para conocer los intereses de la nación. Este conocimiento sólo podía adquirirse con el bienestar, indispensable para la adquisición de las luces y la rectitud del juicio. La propiedad era la única que garantizaba ese bienestar, y sólo ella permite a los hombres ejercer los derechos políticos. Hale señala la influencia que tuvo Constant en Jovellanos, principalmente en lo que se refiere a la participación de la aristocracia como ostentadora de los más altos cargos políticos, lo cual estaba plasmado en la Constitución de Cádiz de 1812. El mismo autor menciona que tanto Constant como el liberalismo de Cádiz van a ser dos fuertes basamentos del liberalismo mexicano de la primera mitad del siglo xIx. Hale, Liberalismo, 1978 , pp. 61-73.

${ }^{80} \mathrm{CAIHY}$, manuscritos, Impresos, c. III-1823, doc. 056,1830 .
Art. 23. Para ser elector de partido se requiere: [Los incisos 1-4, son iguales a los de los electores de parroquial $5^{\circ}$ Poseer una propiedad territorial de 1000 pesos, al menos, o una renta permanente, $o$ un ejercicio, profesión o industria productiva equivalentes a 300 pesos anuales. ${ }^{81}$

Art. 33. Las cualidades necesarias para ser diputados, serán las siguientes.

$1^{\circ}$ Haber dado de un modo inequívoco pruebas de adhesión al actual sistema de gobierno de república central. $2^{\circ}$ Ser ciudadano en el ejercicio de sus derechos. $3^{\circ}$ Ser vecino o natural de esta provincia. Tener 25 años de edad cumplidos. $5^{\circ}$ Poseer una propiedad territorial de 3000 pesos, al menos, o renta permanente, o ejercicio, profesión o industria productiva equivalente a 400 pesos anuales. $^{82}$

La normativa de los procesos electorales en este periodo dio como resultado el control de los mismos, de tal manera que los puestos de elección popular sólo fueron ocupados por reconocidos partidarios del régimen, ${ }^{83}$ quienes en su mayoría habían ya ocupado los mismos niveles desde la convocatoria a elecciones de la Junta de Bécal. Los electos a representantes de partido fueron: ${ }^{84}$

${ }^{81}$ lbid.

82 lbid.

${ }^{83}$ Compárense estos datos con los representantes de la Junta de Bécal, dados en páginas anteriores y véase la parte en donde vecinos del pueblo de Peto piden la sustitución del encargado del cuartel del lugar.

${ }^{84}$ Los siguientes datos fueron tomados del libro de Juan Francisco Molina Solís. Cabe aclarar, que el autor presenta a los políticos de acuerdo con su partido de origen y no conforme a los que les correspondían por decreto. Por ejemplo, tenemos el caso de Pedro Baranda, originario de Campeche, quien meses 
Mérida: Néstor Escudero, José Encarnación Cámara, Miguel Cámara y Sebastián Peón.

Campeche: Pedro Baranda, José Rafael Trava y O'Horan y el presbítero José Mariano de Cicero.

Valladolid: Juan Manuel Godoy, Pedro Gutiérrez y Leonardo Rivero.

Izamal: Manuel Ponce, Eduardo Badillo, y el presbítero José Ramón Cepeda.

Peto: Wenceslao Alpuche, Diego Crisanto Andrade, Manuel María Montalvo y Pío Domingo Reyes.

Tekax: Diego Sosa, José Bonifacio Guzmán, Juan Manuel Ceballos y Rafael Ramírez.

Sotuta: Policarpo Echánove, presbítero José Manuel Pardío y José María Berzunsa.

Hecelchakán: presbítero José Antonino Quijano, Juan Pablo Talavera y Leonardo Trejo.

Hunucmá: Lorenzo Peón.

Tizimín: José Francisco Carvajal y José María Domínguez.

Teabo: Francisco Julián Coello y Andrés María Maldonado. Marrufo.

Seybaplaya: presbítero José María

Carmen: José María Pérez.

Bacalar: José Eulogio Rosado.

En la junta de Calkiní resultaron elegidos al Congreso general: Wenceslao $\mathrm{Al}-$ puche, José Rafael Trava y O'Horan, Sebastián Peón, Manuel José Pardío, Pedro Marcial Guerra, Juan Pío Pérez, Joaquín

antes había sido elegido por el partido de Valladolid. También Sebastián Peón, originario de Mérida, quien había sido seleccionado por el partido del Carmen a la Junta de Bécal. Molina, Historia, 1921, t. I, pp. 93-95.
Gutiérrez Estrada y Néstor Escudero. A dichos personajes se les dieron las instrucciones de pedir al gobierno general la instauración del centralismo; basar las eleciones en cuanto a la instrucción y la propiedad; pedir la exención de los derechos aduanales y cargas sobre el comercio y productos de Yucatán. Sin embargo, los representantes yucatecos fueron rechazados por el gobierno general, lo que más tarde se convirtió en factor importante para que la administración de Carvajal regresara al sistema federal. Sin embargo, el gobierno de Carvajal señaló que los sucesos locales de 1829 no fueron más que una consecuencia de los nacionales de ese mismo año, en los cuales Bustamante, por medios tan controversiales como los de los golpistas yucatecos, había obtenido la presidencia al derrotar a Vicente Guerrero. ${ }^{85}$

${ }^{85}$ Así lo señaló la "Soberana Convención", que era una asamblea general a la que convocó Carvajal para restablecer las relaciones con el gobierno de Bustamante y volver al sistema federal: "que el pronunciamiento por el sistema de gobierno popular representativo central, hecho en 5 de noviembre de 1829, y ratificado por las actas de Bécal y Calkiní, fue impulsado por las circunstancias tan raras como infaustas que rodeaban a la república mexicana, y en particular al estado de Yucatán [...] aunque en diciembre de 1829 apareció en la ciudad de Jalapa el plan por el cual se pronunció el ejército de reserva, para restablecer la observancia de la constitución y de las leyes nacionales, este plan no pudo presentarse a los yucatecos sino como una revolución que tenía unas mismas causas, y que sería justificado o condenado según fuese su ecsito [sic] feliz o desgraciado: no pudiendo entonces formarse un cálculo acertado sobre si produciría un nuevo orden de cosas, un sistema de restauración contraido a las personas; tampoco pudo adoptarse a ciegas [...] lo que no había adoptado toda la nación". Véase CaIHY, manuscritos, Impresos, c. IV-1831, doc. 36. 
A pesar de lo anterior, muchas propuestas y la esencia de las medidas centralistas fueron trasladadas al periodo federalista del régimen de Carvajal, que entre 1831 y 1832 fue reconocido por Bustamante. Así, este primer experimento centralista no murió del todo. No obstante eso es tema de otro trabajo.

\section{CONCLUSIÓN}

La instauración del centralismo yucateco se inició concentrando los descontentos de ciertos sectores de la sociedad esgrimidos contra el gobierno general al estilo jusnaturalista y con tintes contractualistas que se plasmaron al elaborar el acta instituyente de Bécal. Sin embargo, hay que subrayar que en un primer momento fue para ejercer presión. Ya instalado el régimen centralista, el contractualismo en el interior del Estado no sólo se abandona sino se combate, por lo que es importante resaltar las bases de este experimento para no caer en el simplismo de acusar al movimiento centralista como netamente separatista o incongruente, como lo ha hecho parte de la historiografía yucateca desde el siglo XIX.

Más tarde se confirmó lo anterior con el desarrollo del régimen de José Segundo Carvajal, quien desde un principio sustituyó a las autoridades de los pueblos, ya que los cabildos eran los representantes más inmediatos de la soberanía de la comunidad y los que legalizaban los pronunciamientos. Por tal motivo, el control de los ayuntamientos de las dos ciudades más importantes de Yucatán, Mérida y Campeche, era fundamental para sostener a los usurpadores. La figura del jefe político subalterno como brazo del ejecutivo fue crucial para realizar esta tarea y deja notar la visión unitaria que tenían los centralistas al unificar y concentrar la soberanía en los poderes estatales.

Fue claro que desde la época de dominio de la "Liga" la alternancia política no era parte de la cultura política de los yucatecos, a pesar de que al principio y cuando el régimen de Carvajal no estaba legalizado, hubo una aparente apertura para elegir representantes. Las fórmulas electorales utilizadas fueron las planteadas en los tiempos del federalismo y tenían cierta orientación ideológica que tendió al constitucionalismo gaditano, en relación con la participación incluyente de todos los ciudadanos en los puestos de elección, siempre que tuvieran un modo de vivir honesto.

En la práctica podemos notar que los militares no dejaron de participar y controlar el proceso de selección de la junta de Bécal. Aparte de los oficiales militares que irían al pueblo de Bécal, representando a ese grupo, otros más de ellos fueron elegidos en diversos partidos para lo mismo, por ejemplo, en Valladolid y los partidos periféricos del Carmen, Bacalar y Seybaplaya. Los jefes políticos subalternos volvieron a desempeñar un papel importante en las juntas de partido, pues las presidían y sus veredictos eran inapelables.

Los "camarilleros" y los "hombres de bien" yucatecos ocuparon puestos importantes en sus lugares de origen o bien en donde tenían propiedades o eran vecinos. Por ejemplo, Lorenzo Peón en Hunucmá; José de la Cruz Villamil y Pedro Elizalde, ambos miembros del cabildo meridano, en Tizimín y Peto respectivamente.

El acta instituyente de Bécal, tan criticada por los autores decimonónicos, 


\section{SECUENCIG}
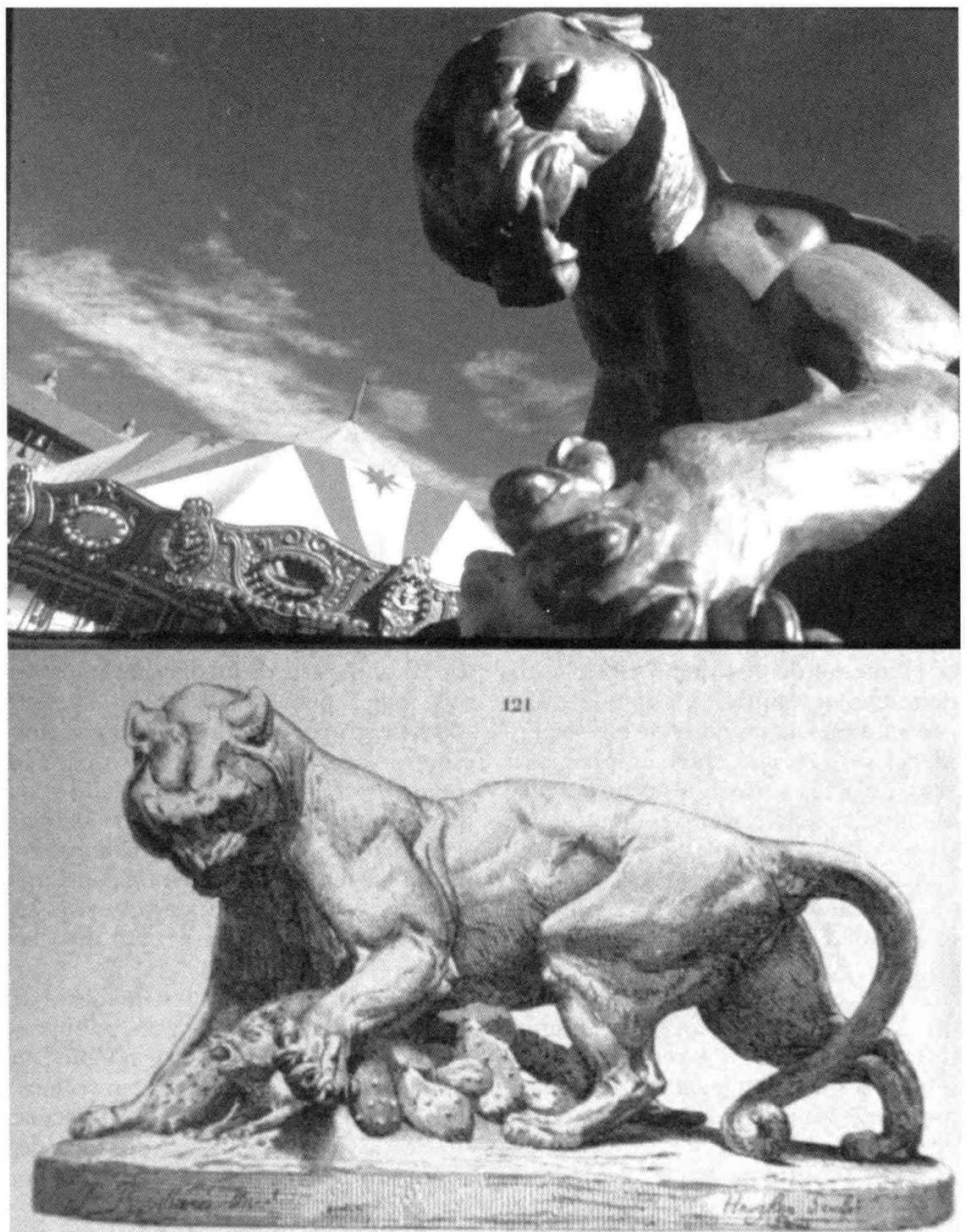

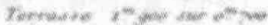


muestra sin embargo que el proyecto de gobierno centralista no era conservador al cien por ciento, ya que tomaba parte del liberalismo gaditano (visión unitaria francesa de nación y proyectos de gobierno); de Locke la defensa de los derechos naturales e individuales; de Montesquieu el principio de división de poderes, y de Constant la democracia dirigida. En suma, liberalismo individualista o burgués. Aunque hubiesen ciertas dosis de jusnaturalismo presentes.

Naturalmente, también se vertió la ideología de personajes como Cicero y Carvajal en cuanto a la necesidad de fortalecer al ejecutivo frente al legislativo y para que el poder judicial fuera quien pusiera los límites al ejecutivo y lo hiciera respetar el pacto social. Es importante resaltar esto, porque las doctrinas extranjeras no se copiaban sino se adecuaban y se utilizaban según la conveniencia de los grupos en el poder.

Las elecciones para diputados al Congreso general en diciembre de 1830 , en el pueblo de Calkiní, dejan ver que efectivamente la alternancia política no formaba parte de la cultura política yucateca. Incluso el centralismo se vuelve más excluyente que el federalismo y el constitucionalismo gaditano. Las ideas de Constant sirven para aumentar los requisitos de riqueza para ocupar puestos electorales, sólo podían obtenerlo la elite más rica de Yucatán. Es decir, se establecían diferencias entre ciudadanos ricos y pobres, y entre los pudientes sólo participaban aquellos que habían manifestado su fervor por el centralismo. En otras palabras, los cargos de elección sólo los podían ocupar los que tuvieran los suficientes requisitos planteados por el restrictivo sistema centralista.
Entonces, en este primer experimento centralista del régimen de Carvajal se observa la búsqueda de equilibrio de poderes o la efectividad de los mismos, fortaleciendo al ejecutivo y al judicial y suprimiendo al Congreso. También se trata de establecer un control sobre la soberanía de los cabildos y la ciudadanía a través de los jefes políticos subalternos y la democracia dirigida. Para construir esto, los actores políticos recurren a bases ideológicas que remiten a autores liberales como Locke, Constant y Montesquieu, pero también con prácticas del antiguo régimen al concentrar demasiadas atribuciones en el poder ejecutivo y manifestar prácticas excluyentes. Todo lo precedente muestra parte importante de la cultura política yucateca en la temporalidad estudiada.

\section{ARCHIVOS}

AGEY Archivo General del Estado de Yucatán. CAIHY Centro de Apoyo a la Investigación Histórica de Yucatán.

\section{HeMEROGRAFíA}

La Concordia Yucateca, 1830.

BIBLIOGRAFÍA

-Abreu de la Torre, M. P., Reminiscencias históricas campechanas, Ediciones de la Universidad de Campeche, Campeche, 1964, t. I.

- Alcocer Bernés, José Manuel, Historia del Ayuntamiento de Campeche, 1540-1991, Ayuntamiento de Campeche, Campeche, 1991 (Colección San Francisco de Campeche). 
-Álvarez, Francisco, Anales bistóricos de Campeche, Ayuntamiento de Campeche/Editorial Maldonado, Mérida, 1991, t. I (Colección San Francisco de Campeche).

-Ancona, Eligio, Historia de Yucatán, Universidad Autónoma de Yucatán, Mérida, 1978, t. 피.

- Colección de leyes y decretos del Augusto Congreso del Estado libre de Yucatán, Tipografía de G. Canto, Mérida, 1896, t. II.

-Annino, Antonio, Historia de las elecciones en Iberoamérica, siglo XIX, FCE, México, 1995.

___ "Nuevas perspectivas para una vieja pregunta" en El primer, 1995, pp. 43-91.

___, "Prácticas criollas y liberalismo en la crisis del espacio urbano colonial" en Montalvo, Aguila, 1995, pp. 17-63.

___ , "Ciudadanía versus gobernabilidad republicana en México. Los orígenes de un dilema" en Sábato, Ciudadanía, 1999, pp. 62-93.

- Aznar Pérez, Antonio, Colección de leyes, decretos y órdenes, Imprenta de Rafael Pedrera, Mérida, 1849 , t. I.

-Baños Ramirez, Othón (comp.), Liberalismo, actores y política, Universidad Autónoma de Yucatán, Mérida, 1995.

-Baqueiro Preve, Serapio, Ensayo bistórico sobre las revoluciones en Yucatán, desde el año de 1840 basta 1864, Universidad Autónoma de Yucatán, Mérida, 1990, t. I.

-Barragán Barragán, José, Introducción al federalismo, UNAm, México, 1978.

__ "Breve comentario sobre las leyes constitucionales de 1836" en Galeana, México, 1999, pp. 115-131.

-Bellingeri, Marco, "Del voto a las bayonetas: poder y liberalismo en el Yucatán constitucional e independiente" en Montalvo, Aguila, 1995, pp. 91-119.

—, "Soberanía o representación: legitimidad de los cabildos y la conformación de las instituciones liberales en Yucatán" en Montalvo, Águila, 1995, pp. 65-89.
, "Las ambiguiedades del voto en Yucatán. Representación y gobierno en una formación interétnica" en Annino, Historia, 1995, pp. 227-290.

-Berstein, Serge, "La cultura política" en Jean Pierre Rioux y Jean François Sirinelli, Para una bistoria cultural, Taurus, México, 1997, pp. 389-405.

-Betancourt Pérez, Antonio y José Sierra Villareal, Yucatán una historia compartida, Instituto Mora/sep/Gobierno del Estado de Yucatán, México, 1989.

-Bobbio, Noberto, La teoría de las formas de gobierno en la bistoria del pensamiento político, $\mathrm{FCE}$, México, 2000.

- Nicola Mateucci y Gianfranco Pasquino, Diccionario de política, Siglo XXI, México, 1997 , t. II.

-Burgerie, André, "La antropología histórica" en La nueva historia, bajo la dirección de Jacques LeGoff, Roger Chartier y Jacques Revel, El Mensajero, Bilbao, 1986, pp. 91-117.

-Campos García, Melchor, "La política en una etapa de crisis económica, regionalismo, autonomía y separatismo", tesis de maestría, FFyL-UNAM, México, 1995.

—, "La influencia de la tradición jurídica española en el separatismo yucateco" en Baños, Liberalismo, 1995, pp. 23-56.

__ , "Autonomía y separatismo en Yucatán: las opciones de una revolución incompleta, 1840-1848", tesis de doctorado, Instituto de Ciencias Sociales y Humanidades-Benemérita Universidad Autónoma de Puebla, Puebla, 1999.

-Carmagnani, Marcello (coord.), Federalismos latinoamericanos, México, Brasil, Argentina, $\mathrm{FCE}$, México, 1996.

__ _ _ "Territorios, provincias y estados: las transformaciones de los espacios políticos en México, 1750-1850" en Vázquez (coord.), Fundación, 1994, pp. 39-109.

-Castillo Canche, Jorge y Armando Chi Estrella, "El pronunciamiento de Santiago Imán 
por el federalismo y su restablecimiento en Yucatán", Revista de la Universidad Autónoma de Yucatán, núm. 207, octubre-diciembre de 1998, Mérida, pp. 13-23.

-Castillo Canche, Jorge y Roger Domínguez Zaldívar, "El impacto de la Constitución de Cádiz en Yucatán", tesis de licenciatura, Facultad de Ciencias Antropológicas-UADY, Mérida, 1986.

-Costeloe, Michael P., La primera república federal de México (1824-1835), FCE, México, 1975.

- La repuiblica central en México, 18351846, FCE, México, 2000.

-Derechos del pueblo mexicano. México a través de sus constituciones, Cámara de Diputados, XIVI Legislatura del Congreso de la Unión, México, 1965.

-Di Tella, Torcuato, Política nacional y popuLar en México, 1820-1847, FCE, México, 1994.

-El primer liberalismo mexicano: 1808-1854, Museo Nacional de Historia-INAH, México, 1995.

-Galeana, Patricia (comp.), México y sus constituciones, FCE/AGN, México, 1999.

-Guerra, François-Xavier, México: del antiguo régimen a la revolución, FCE, México, 1988, t. I. , "El soberano y su reino. Reflexiones como la génesis del ciudadano en América Latina" en Sábato (coord.), Ciudadania, 1999, pp. 33-61.

-Güiemez Pineda, Arturo, Liberalismo en tieras del caminante. Yucatán 1812-1840, El Colegio de Michoacán/UADY, Zamora, 1994.

-Hale, Charles, El liberalismo mexicano en la época de Mora, Siglo XXI, México, 1978.

-Irigoyen Rosado, Renán, "Incorporación federalista de Yucatán a México", Revista de la Universidad de Yucatán, vol. xv, núms. 87-88, junio-agosto de 1973, Mérida, pp. 33-50.

-Jardin, André, Historia del liberalismo politico. De la crisis del absolutismo a la Constitución de 1875, FCE, México, 1989.

-Lanz, Manuel A., Compendio de historia de Campeche, El Fénix, Campeche, 1905.
-Locke, John, Ensayo sobre el gobierno civil, Aguilar, Madrid, 1976.

-Merquior, José Guilherme, Liberalismo viejo y nuevo, FCE, México, 1993.

-Molina Solís, Juan Francisco, Historia de Yucatán: desde la independencia basta la época actual, Talleres Gráficos de la Revista de Yucatán, Mérida, 1921, t. I.

-Montalvo Ortega, Enrique (coord.), El águila bifronte. Poder y liberalismo en México, INAH, México, 1995 (Divulgación).

- "Liberalismo y libertad de los antiguos (el siglo XIX y los orígenes del autoritarismo mexicano)" en Montalvo (coord.), Aguila, 1995, pp. 243-277.

-Montesquieu, Del espiritu de las leyes, Porrúa, México, 1998 (Sepan Cuantos, 191).

-Mora, José María Luis, "Catecismo político de la federación mexicana" en Derechos, 1965.

-Poot Capetillo, Efraín y Janet Paredes Guerrero, "La cultura política en Yucatán" en Baños, Liberalismo, 1995, pp. 359-378.

-Rabasa Gamboa, Emilio, De súbditos a ciudadanos. Sentido y razón de la participación politica, UNAM/ Porrúa, México, 1994.

-Reyes Heroles, Jesús, El liberalismo mexicano: la sociedad fluctuante, FCE, México, 1994, t. II.

-Rodríguez Losa, Salvador, Geografía politica de Yucatán, Universidad Autónoma de Yucatán, Mérida, 1985, tt. I-II.

-Rousseau, Juan Jacobo, El contrato social, Dante, México, 1988.

-Rubio Mañé, Ignacio y Salvador Rodríguez Losa, Alcaldes de Mérida de Yucatán (1941-1992), Universidad Autónoma de Yucatán, Mérida, 1992.

-Sábato, Hilda (coord.), Ciudadanía política y formación de naciones. Perspectivas históricas de América Latina, Fideicomiso Historia de las Américas-COLMEX/FCE, México, 1999.

-Sierra, Carlos Justo, Breve bistoria de Campeche, FCE/COLmex, México, 1998. 
-Sordo Cedeño, Reynaldo, El Congreso en la primera república centralista, COLMEX/ITAM, México, 1993.

_, "El Congreso y la formación del Estado-nación en México, 1821-1855" en Vázquez, Fundación, 1994, pp. 135-178.

"El grupo centralista y la Constitución de las Siete Leyes, 1835-1837" en Galeana, México, 1999, pp. 96-114.

-Tena Ramírez, Felipe, Leyes fundamentales de México 1808-1967, Porrúa, México, 1967.

-Vázquez, Josefina Zoraida (coord.), La fundación del Estado mexicano, Nueva Imagen, México, 1994.

"De la difícil constitución de un Estado: México, 1821-1854" en Vázquez, Fundación, 1994, pp. 9-37.

—_, "México, la ilustración y el liberalismo, 1750-1860" en Primer, 1995, pp. 11-41.
-, "El federalismo mexicano, 18231847 " en Carmagnani, Federalismos, 1996, pp. $15-50$. , "El contexto histórico del constituyente de 1824" en Galeana, México, 1.999, pp. $78-88$.

-Yucatán a través de sus constituciones 18231918. Colección de bistoria legislativic, LI Legislatura del H. Congreso Constitucional del Estado Libre y Soberano de Yucatán, Mérida, 1989.

-Zanolli Fabila, Betty Luisa, "Tiberalismo y monopolio: orígenes del federalismo en las tierras del Mayab", tesis de licenciatura, FFyLUNAM, México, 1989.

-Zavala, Silvio, Apuntes de bistoria nacional, 1808-1974, FCE, México, 1996. 